\title{
HEINONLINE
}

Citation: 43 Duke L.J. 337 1993-1994

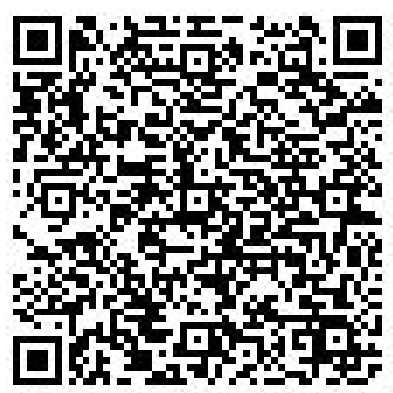

Content downloaded/printed from

HeinOnline (http://heinonline.org)

Mon Nov 23 10:52:28 2015

-- Your use of this HeinOnline PDF indicates your acceptance of HeinOnline's Terms and Conditions of the license agreement available at http://heinonline.org/HOL/License

-- The search text of this PDF is generated from uncorrected OCR text.

-- To obtain permission to use this article beyond the scope of your HeinOnline license, please use:

https://www.copyright.com/ccc/basicSearch.do?

\&operation $=$ go\&search $\mathrm{Type}=0$

\&lastSearch $=$ simple\&all=on\&titleOrStdNo=0012-7086 


\title{
NOTES
}

\section{STOLEN ARTWORK: DECIDING OWNERSHIP IS NO PRETTY PICTURE}

\author{
ANDREA E. HAYWORTH†
}

\section{INTRODUCTION}

In the United States, where art is no longer mere exhibition fare but an investment worth millions of dollars, it is a curious anomaly that our legal system may favor the person who steals a priceless piece of art over an innocent purchaser who unknowimgly buys it to hang on his hiving room wall. This tension has not gone unnoticed, but it remains unresolved. The New York Court of Appeals acknowledged the problem in its recent decision in Solomon R. Guggenheim Foundation v. Lubell. ${ }^{1}$

The rule in this State is that a cause of action for replevin against the good-faith purchaser of a stolen chattel accrues when the true owner makes demand for return of the chattel and the person in possession of the chattel refuses to return it.... Although seemingly anomalous, a different rule applies when the stolen object is in the possession of the thief. In that situation, the Statute of Limitations runs froin the time of the theft, even if the property owner was unaware of the theft at the time that it occurred. ${ }^{2}$

The court did not fail to recognize the curiosity of this arrangement. When a thief steals a painting, the statute of limitations begins to run immediately. After the limitations period expires, the thief is immune to suit and has thereby achieved re-

$\dagger$ The author wishes to thank Professor Richard C. Maxwell of the Duke University School of Law for his guidance and support of this project.

1. 569 N.E.2d 426 (N.Y. 1991).

2. Id. at 429 (emphasis added) (citations omitted). The court further noted that in a replevin action against a good-faith purchaser of stolen art, the possession is not considered wrongful under state law until a demand for possession is made and refused. See infra text accompanying notes 124-28. 
pose. ${ }^{3}$ By contrast, an innocent purchaser of the same painting is subject to a number of equitable doctrines that toll the statute of limitations on the true owner's replevin action. The purchaser's claim to the painting, for which valuable consideration presumably has been paid, is determined in hight of any number of factors; depending on the jurisdiction, the true owner's exercise of due diligence, ${ }^{4}$ the fulfillment of the requirements for adverse possession, ${ }^{5}$ or the owner's unsuccessful demand for return of possession may be relevant. ${ }^{6}$ The innocent purchaser may never actually achieve repose. ${ }^{7}$ In practical terms, therefore, a thief may stand a better chance of retaining possession of a piece of stolen artwork than an innocent purchaser. ${ }^{8}$

3. In New York, the statute that governs actions to recover a stolen chattel mandates commencement of proceedings within three years of the time the action accrues. See N.Y. CIV. PRAC. L. \& R. § 214(3) (McKinney 1990). The time of accrual is, in fact, what distinguishes the two scenarios presented in this discussion. New York courts have held that a cause of action against a thief accrues at the time of the dispossession. See Sporn v. MCA Records, Inc., 448 N.E.2d 1324, 1326-27 (N.Y. 1983) (holding that the statutory period begins to run at the time of the conversion).

4. See, e.g., O'Keeffe v. Snyder, 416 A.2d 862, 869-70 (N.J. 1980) (applying the discovery rule, previously applicable to medical malpractice actions, to replevin actions for recovery of stolen art and imposing a duty on the true owner to use all reasonable efforts to locate a stolen piece).

5. Reynolds v. Bagwell, 198 P.2d 215, 216-17 (Okla. 1948) (applying the traditional test of adverse possession to recovery of stolen chattel and concluding that absent fraud or concealment by the subsequent possessor, the traditional analysis of ownership resulting from expiration of the statutory period applies).

6. In New York, suits against innocent purchasers accrne only when the true owner makes a demand for possession, and the purchaser refuses to return the property. See, e.g., Guggenheim, 569 N.E.2d at 429; Menzel v. List, 246 N.E.2d 742 (N.Y. 1969). Under this doctrine, the purchaser has little chance of attaining repose because the true owner may at any time demand possession of the property. Only when the purchaser refuses to deliver possession does the limitations period begin to run. Guggenheim, 569 N.E.2d at 429.

California has the only statute codifying the specific time at which a cause of action accrues for actions to recover stolen artwork. See CAL. CIV. PROC. CODE § 338(c) (West Supp. 1993). The statute of limitations requires commencement of proceedings

[w]ithin three years ... [of a]n action for taking, detaining, or injuring any goods or chattels, including actions for the specific recovery of personal property. The cause of action in the case of theft ... of any article of ... artistic significance is not deemed to have accrned until the discovery of the whereabouts of the article by the aggrieved party, his or her agent, or the law enforcement agency which originally investigated the theft.

Id. While this statute does not foreclose the application of additional equitable doctrines, such as the discovery rule, see infra text accompanying note 66 , it does specifically detail the point at which the owner's cause of action accrnes.

7. See supra note 6 .

8. It is outside the scope of this Note to discuss in depth the validity of the policy 
To art collectors, museums, and other victims of art theft, the uncertainty surrounding the determination of their possessory rights to pieces of art is far from insignificant. The narrowness of the issue belies its importance. As art prices have soared, so has art theft. ${ }^{9}$ With masterpieces selling for upwards of $\$ 50$ million apiece, thieves no doubt see possibilities in such a lucrative business. ${ }^{10}$ The stolen art market has an annual trade estinnated at between $\$ 860$ million and $\$ 2.6$ billion; ${ }^{11}$ trafficking in stolen art is second only to drug trafficking as the most lucrative form of criminal activity. ${ }^{12}$

In the first eight months of 1988 (a year in which two Vincent Van Gogh paintings sold for over $\$ 93$ million), at least 9000 art thefts were reported. ${ }^{13}$ Without a doubt, the actual incidence of art theft is even higher. Numerous thefts are never reported because owners and museums, embarrassed by the breach of security, fear that collectors will be reluctant to loan their valuable pieces,

considerations involved in the statute of limitations as it applies to thieves. Instead, this Note focuses on the statute of limitations as it has been applied and modified in regard to innocent purchasers. Discussion of the limitations period applicable to thieves is included to highlight the treatment of innocent purchasers.

9. Renee Graham, Art Stolen from Gardner Museum Was Uninsured: Thieves May Find the Booty "Too Hot to Handle," Boston GloBE, Mar. 20, 1990, at 6.

10. Id; see also Dalya Alberge, Statues Worth 1100,000 Stolen from Gallery, THE INDEPENDENT, Apr. 24, 1992, at 3 (discussing insurance company officials' concern that the skyrocketimg prices fetched by legitimately sold pieces of art were fueling art theft); Daniel Golden, Hot Art: The Billion Dollar Business, Boston GLOBE, Feb. 12, 1989, (Magazine) at 63 (Rising art prices and art theft are "intimately related .... They are both part of the general fetishization of works of art that has taken place in society, particularly in America. Art is no longer priceless, it is priceful. We overvalue art, and then we're surprised when the chalices are stolen.") (quoting Robert Hughes, art critic for Time magazine).

11. Kate Dourian, Art Theft to Be Major Problem when Borders Come Down in 1992, REUTERS, Sept. 16, 1991, available in LEXIS, Nexis Library, WIRES File. The article notes that Italy loses 245,000 works of art a year to theft, and Britain loses 5,000 paintings annually. It also expresses the concern among police and art experts that the opening of the borders in Europe would cause an explosion of the illicit trade because of the ease with which thieves may travel among countries. Id.

12. Id.

13. Graham, supra note 9, at 6 . These figures were obtamed from Interpol, an agency closely connected to investigation of art theft on the international scene in an official pohice capacity. Other agencies also take reports of stolen artwork, including the International Federation of Art Research (IFAR). Robert Hughes, A Boston Theft Reflects the Art World's Turmoil, TrMe, Apr. 2, 1990, at 54, 55. Another organization recording reports of art theft is the London-based Art Loss Register (ALR), which charges a fee to record the theft but allows police free access to the records. ALR also has offices in New York City. Dourian, supra note 11. 
or have other personal reasons that counsel against reporting. ${ }^{14}$ Furthermore, almost ninety percent of stolen artwork is never found. ${ }^{15}$

Since World War II, the United States has been the biggest market for illegal art. ${ }^{16}$ The paltry police resources devoted to recovery of stolen art in the United States makes the possibility of recovery bleak. In 1989, only two pohice officers were enıployed to investigate such thefts full time, one in New York City and one in Los Angeles. The Federal Bureau of Investigation had no agents exclusively investigating art theft. ${ }^{17}$

The delays and obstacles involved in recovery of stolen art create problems for both purchasers and true owners. In most cases, true owners do not locate stolen works until the statute of limitations has long since run on their clains for recovery of the property. As a result, the statute of linitations historically has served as a purchaser's primary protection against liability for replevin of stolen pieces. ${ }^{18}$ However, courts' application of various equitable doctrines to niodify the statute of limitations has han1pered both true owners' and innocent purchasers' understanding of their respective rights and obligations in dealing with stolen art. Purchasers are often left in doubt about what protection, if any, they have against claims for replevin: "[C]ollectors used to ask [art connoisseurs] ... if soniething was good. Now they have a phalanx of lawyers telling thein whether it's legal . .."19 However, in its decision in Solomon R. Guggenheim Foundation v. Lubell, the New York Court of Appeals adopted an approach, based on the requirement of a deniand to commence the running of the statute, that offers equity and certainty, is realistic in its expecta-

14. See Golden, supra note 10 , at 16 .

15. See Hughes, supra note 13 , at 55 .

16. Alan Riding, French Museum Chief vs. Art Thieves, N.Y. Times, June 15, 1991, at 13,15 .

17. Golden, supra note 10 , at 36 .

18. Stephen L. Foutty, Recent Development, Autocephalous Greek-Orthodox Church of Cyprus v. Goldberg \& Feldman Fine Arts, Inc.: Entrenchment of the Due Diligence Requirement in Replevin Actions for Stolen Art, 43 VAND. L. Rev. 1839, 1841 (1990).

19. Alexander Stille, Was This Statue Stolen?, NAT'L L.J., Nov. 14, 1988, at 32 (quoting James F. Fitzpatrick, a partner in the Washington, D.C. law firm of Arnold \& Porter, who serves as counsel to the American Association of Dealers in Ancient, Oriental and Primitive Art). Although this statement was made with reference to the antiquities trade, it seems equally applicable to purchasers of valuable pieces of art, who often have been confused by the state of the law as to their rights to these pieces. 
tions of the parties, and is consistent with the traditional understanding of property ownership. ${ }^{20}$

With the trade in illegal art reaching overwhelming proportions, a need-some might say an urgency-clearly exists for an approach like that taken by the Guggenheim court that clarifies when innocent purchasers inay vahidly assert a statute of himitations defense in a trne owner's suit for return of stolen art. This Note discusses the various approaches that courts have taken to the statute of limitations defense and determines that the approach based on the demand rnle best satisfies the need for clarity in this area.

Part I briefly discusses the statute of limitations and its general function in replevin actions. Part II analyzes developments in the statute of limitations defense, including a more in-depth view of the adverse possession defense, the discovery rule and its requirement of due diligence, and the demand rule. Part III focuses specifically on Guggenheim and the strengths of this significant decision. It concludes that, despite its perceived drawbacks, the demand rule upheld in Guggenheim best serves the public interest because it adheres to traditional property and commercial law concepts as well as to federal statutory law. This approach also best communicates what is expected of both innocent purchasers seeking to prevent true owners from obtaining return of their stolen artworks and true owners who have delayed either in searching for a stolen piece or in seeking its return.

\section{A General Discussion of tHe Statute of Limitations}

\section{A. General Function of the Statute of Limitations}

A plaintiff seeking the return of a stolen piece of art has a cause of action in replevin. ${ }^{21}$ Replevin deinands return of an itein in lieu of dainages or criminal prosecution of the possessor. ${ }^{22} \mathrm{~A}$

20. Solomon R. Guggenheim Found. v. Lubell, 569 N.E.2d 426, 429 (N.Y. 1991).

21. See Autocephalous Greek-Orthodox Church of Cyprus v. Goldberg \& Feldman Fine Arts, Inc., 717 F. Supp. 1374, 1388 (S.D. Ind. 1989) (applying Indiana law), affd, 917 F.2d 278 (7th Cir. 1990), cert. denied, 112 S. Ct. 377 (1992).

22. See BLACK's LAW Dictionary 1299 (6th ed. 1990) (defining replevin as "[a]n action whereby the owner or person entitled to repossession of goods or chattels may recover those goods or chattels"); Leah E. Eisen, Commentary, The Missing Piece: A Discussion of Theft, Statutes of Limitations, and Title Disputes in the Art World, 81 J. CRM. L. \& CRIMINOLOGY 1067, 1072 (1991). 
true owner, however, may not pursue an action in replevin after the expiration of the statutory limitations period. ${ }^{23}$ It is this preclusive effect that is of significance in this discussion.

A statute of limitations is intended to prescribe the time during which a party may raise a claim in legal proceedings. It is designed to "stimulate to activity and punish neghigence' and promote repose by giving security and stability to human affairs."24 In Riddlesbarger v. Hartford Insurance Co. ${ }^{25}$ the U.S. Supreme Court explained that a statute of limitations is founded on the notion that

[t]he lapse of years without any attempt to enforce a demand creates, therefore, a presumption against its original validity, or that it has ceased to subsist. This presumption is made by these statutes a positive bar; and they thus become statutes of repose, protecting parties from the prosecution of stale claims, when, by loss of evidence from death of some witnesses, and the imperfect recollection of others, or the destruction of documents, it might be impossible to establish the truth. ${ }^{26}$

A statute of limitations is beheved to make pursuit of a claim both more fair and more efficient. ${ }^{27}$ One author suggests that fairness to the defendant is indeed the "primary consideration" underlying the statute of limitations defense because "[t]here conies a time when [the defendant] ought to be secure in his reasonable expectation that the slate has been wiped clean of ancient

23. See Ray A. Brown, The Law of Personal Property § 4.1, at 33 (Walter B. Raushenbush ed., 3d ed. 1975).

24. Mary K. Devereaux, Note, Battle Over a Monet: The Requirement of Due Dillgence in a Lawsuit by the Owner Against a Good Faith Purchaser and Possessor, LoY. ENT. L.J. 57, 62 (1989) (quoting Wood v. Carpenter, 101 U.S. 135, 139 (1879)); see also Leake, v. Bullock, 250 A.2d 27, 29 (N.J. Super. Ct. App. Div. 1969) ("Statutes of limitation ... are intended to run against those who are neglectful of their rights and who fail to use reasonable and proper diligence in the enforcement thereof.").

25. 74 U.S. (7 Wall.) 386 (1868).

26. Id. at 390; see also Basque v. Yuk Lin Liau, 441 P.2d 636, 637 (Hav. 1968) (relying on a presumption that people do not voluntarily delay in making genuine claims).

27. Foutty, supra note 18, at 1842 (suggesting that statutes of limitations condemn delays in filing a cause of action as an undue burden on the purchaser). Another commentator has suggested that "[a] defendant who does not imagine that any claim may be brought against him is not only likely to have parted with evidence that he at one time had but is also likely to have lost track of evidence which at one time he could have obtained." Jeremy S. Williams, Limitation Periods on Personal Injury Claims, 48 NOTRE DAME LAW. 881, 884 (1973). 
obligations. ${ }^{\$ 28}$ In addition to protecting a defendant, a statute of limitations is also punitive, depriving a plaintiff of his claim if he does not act promptly in support thereof. ${ }^{29}$

Statutes of limitations serve another important function in replevin actions. "[I]n the world of commerce and trade, they provide stability by assuring that those who have dealt in good faitl with property will be niade secure in their possession after a certain period of time. In this way, the statutes reduce uncertainty and proinote free trade of goods." ${ }^{.30}$ The bustling commerce of today's world would certainly be adversely affected if buyers could lave no assurance that their title to goods was valid.

The length of time statutes of limitations prescribe varies by jurisdiction; ${ }^{31}$ more important for the purposes of this discussion is the point at which the cause of action accrues. Most statutes of limitations are vague on this point, ${ }^{32}$ providing only that the limitations period runs for a number of years from the time at which the cause of action accrues. ${ }^{33}$ Courts are thereby given broad dis-

28. Note, Developments in the Law: Statutes of Limitation, 63 HARV. L. REV. 1177, 1185 (1950); see also John G. Petrovich, Comment, The Recovery of Stolen Art: Of Paintings, Statues, and Statutes of Limitations, UCLA L. REV. 1122, 1127 (1980); Order of R.R. Telegraphers v. Railway Express Agency, Inc., 321 U.S. 342, 349 (1944) ("The theory is that even if one has a just claim it is unjust not to put the adversary on notice to defend within the period of limitation and that the right to be free of stale claims in time comes to prevail over the right to prosecute them.").

29. See Eisen, supra note 22, at 1072. The author suggests that this rationale is based on the notion of a "'sleeping claimant' who intentionally or negligently postpones bringing an action." Id. at 1072-73. It presumes that a person with a valid claim will not delay in pursuing the cause of action. Id. at 1073; see also Basque, $441 \mathrm{P} .2 \mathrm{~d}$ at 637 (relying on the presumption that people do not voluntarily delay in prosecuting authentic claims).

30. Petrovich, supra note 28 , at 1128 . This function is worthy of note because the equitable doctrines applied to a statute of limitations do not always fulfill this goal, and each court's modification to a statute indicates the emphasis it places on this rationale as a valid policy goal.

31. See, e.g., CaL. Civ. Proc. Code § 338(3) (West Supp. 1993) (three years); Fla. STAT. ANN. \& 95.11(i) (West 1982) (four years); N.Y. Crv. PRAC. L. \& R. \& 214(3) (McKinney 1990) (three years); OHIO REv. CODE ANN. \& 2305.09 (Baldwin 1992) (four years); TEX. CIV. PRAC. \& REM. CODE ANN. \& 16.003(a) (West 1986) (two years).

32. See, e.g., Fernandi v. Strully, 173 A.2d 277, 285 (N.J. 1961) ("Although New Jersey's Legislature has provided that every action at law for injury to the person shall be brought within two years after the cause of action shall have accrued, it has ... never sought to define or specify when a cause of action shall be deemed to have accrued .....").

33. For example, California's introductory statute provides that "[c]ivil actions, without exception, can only be commenced within the periods prescribed in this title, after the cause of action shall have accrued." CAI. CIV. PROC. CODE $\$ 312$ (West 1982). This 
cretion to determine whether a cause of action has accrued. This discretion requires them to ascertam if specific events have occurred ${ }^{34}$ Rather than focusing on a particular time, a court must look to the actions and events that constitute the cause of action. ${ }^{35}$ In replevin actions, an owner's cause of action typically accrues at the time his property is stolen, regardless of whether he knows the identity of the thief or that his property is missing, ${ }^{36}$ unless the thief or subsequent possessor actively conceals the property, preventing open and notorious possession. ${ }^{37}$

Courts have long recognized that a wrongful taking does not deprive the owner of the right to possess the property. However,

provision is followed by a string of statutes prescribing the number of years afforded a plaintiff to assert certain types of claims.

34. "A cause of action comes into existence and thereby accrues when all the elements necessary to establish . . . hability occur." Williain G. Crimmins, Comment, The Evolution of Illinois Tort Statutes of Limitation: Where Are We Going and Why?, 53 CHI.-KENT L. REV. 673, 677 (1977) (emphasis in original).

35. Petrovich, supra note 28 , at $1128-29$. The cause of action is specifically said to accrue when the last of the prerequisites for that cause of action occurs. Id.

36. In fact, this is generally the case when the victim pursues an action against the thief. See supra text accompanying note 3 .

37. Courts are generally in agreement that the statute of limitations is tolled during a period of wrongful or intentional concealment of stolen property. See, e.g., Jackson v. American Credit Bureau, Inc., 531 P.2d 932, 936 (Ariz. Ct. App. 1975); Joseph v. Lesnevich, 153 A.2d 349, 357 (N.J. Super. Ct. App. Div. 1959); Reynolds v. Bagwell, 198 P.2d 215, 217 (Okla. 1948). The suspension of the limitations period continues until the property is held in open and notorious possession. Courts generally place a subsequent possessor with notice of the theft in the same position as the thief himself, and any concealment by either will suspend the statute. See Petrovich, supra note 28, at 1131-32 n.36.

Concealment must result from the possessor's affirmative act; failure to publicize possession is not sufficient. Reynolds, $198 \mathrm{P} .2 \mathrm{~d}$ at 217 (citing United States v. One Stradivarius Kieserwetter Violin, 197 F. 157, 158 (2d Cir. 1912)). This presents a curious situation in the case of stolen artwork because possession of art is normally inconspicuous. Pieces of art are often kept in private collections. See infra note 59. In many cases, fraudulent concealment is not substantially different from good-faith possession. See Petrovich, supra note 28 , at 1131-32 n.36. This curiosity may account for courts' willingness to abandon the mechanical application of the statute of limitations in actions for recovery of stolen artwork; open and notorious possession may be virtually impossible to establish. To highlight this poimt, one court observed that

if jewelry is stolen from a municipality in one county in New Jersey, it is unlikely that the owner would learn that someone is openly wearing that jewelry in another county or even in the same municipahity. Open and visible possession of personal property ... may not be sufficient to put the original owner on actual or constructive notice of the identity of the possessor. The problem is even more acute with works of art.

O'Keeffe v. Snyder, 416 A.2d 862, 871. (N.J. 1980). For a more detailed discussion of this topic, see Petrovich, supra note 28, at 1131-32 n.36. 
because the statute of limitations operates to bar an owner's action to recover the property, apphication of this principle can create a "right without a remedy." Recognition of this futile right has propelled the courts to consider the desirability of sacrificing mechanical apphication of the statute of limitations in favor of equitable tolling doctrines. Although the courts could make determinations of apphicability on a case-by-case basis, they prefer to modify statutes of limitations through "manipulation of the definition of the 'accrual' of a cause of action." ${ }^{39}$ The resulting doctrines reflect judicial imterest in the development of a more pohicy-directed application of the statute of limitations.

\section{B. Statutes of Limitations Applied to Thieves}

In actions for recovery of personal property, the original $\mathrm{m}$ tent belimd the statute of limitations was to allow a suitable period in which the owner could claim his stolen property from the thief. During this time, the thief had the opportumity to establish adverse possession. In the event the owner failed to assert his claim, the thief's possession ripened into valid title. The owner was thereby pumished for his failure to press the claim; in a sense, the owner's delay, rather than the runming of the statute, vested title in the thief.

To receive this benefit, the thief not only had to take possession of the property but also had to prove that the possession was hostile to the owner, for example, by refusing the owner's demand for return of the property. In addition, the thief's possession was required to be open and notorious. ${ }^{40}$ The need for open and no- torious possession led to the creation of the exception for fraudulent concealment: a thief is not allowed to conceal the whereabouts of the property and later claim the statute of limitations as a defense. ${ }^{41}$ This exception underscores the importance of adverse

38. Kathleen F. Brickey, The Jurisprudence of Larceny: An Historical Inquiry \& Interest Analysis, 33 VAND. L. REV. 1101, 1113 n.75 (1980).

39. Eisen, supra note 22 , at 1074.

40. BROWN, supra note $23, \S 4.2$. Secret possession is often presumed when the thief is holding property. Id. (citing Lightfoot v. Davis, 91 N.E. 582 (N.Y. 1910); Commercial Union Ins. Co. v. Connolly, 235 N.W. 634 (Minn. 1931)).

41. Adams v. Coon, 129 P. 851,852 (Okla. 1913) (citing Gatlin v. Vaut, 91 S.W. 38, 39 (Indian Terr. 1905)) (holding that if the thief had held the property openly and notoriously in the area from which the property was stolen, he could have pled the statute of limitations, but if he concealed the property, the running of the statute would be sus- 
possession to the operation of the statute as to thieves. Unlike the case of the innocent purchaser, in which determining that the true owner lost possession by theft is vital, the inquiry in cases involving thieves centers on whether the thief has inaintained open and notorious possession. ${ }^{42}$

In applying this law, courts have split in determining whether the operation of the statute strips the true owner of title or merely prevents an action against the thief. In Garrett v. Vaughan, ${ }^{43}$ the Supreine Court of Tennessee indicated that the running of the statute in conjunction with the operation of adverse possession transferred title, but the running of the statute alone did not. ${ }^{44}$ Other cases suggest that the statute itself operates to transfer to the thief title paramount to that of the true owner. ${ }^{45}$ The difference concerns only the status of the title to the property; in both cases, the thief retains possession. An innocent purchaser, however, is in a different position than a thief, and this difference in status has prompted courts to attempt to nodify the statute of limitations in actions to recover stolen artwork from iunocent purchasers. The appropriate modification is the subject of inuch confusion.

pended until the property was returned to the area and openly held, so that the owner might have a reasonable opportunity to discover its whereabouts).

42. Garrett v. Vaughan, 60 Tenn. 113, 119-20 (1873); see also Chilton v. Carpenter, 189 P. 747, 749 (Okla. 1920) (quoting Gatlin, 91 S.W. at 39) (requiring possession in an open and notorious manner for the statute to accrue to the benefit of the thief); Torrey v. Campbell, 175 P. 524, 525 (Okla. 1918) (requiring that the thief hold the property openly and notoriously in order to start the statute running).

43. 60 Tenn. 113 (1873).

44. The court highlighted its conclusion by saying that the statutes which vest the title upon an adverse possession of property, rest upon a different footing from those statutes of limitation which merely bar a debt. The first operates on the right; the second on the remedy.... [T] statute acts upon the title, and when the bar is perfect, transfers the property to the adverse possessor, while in contracts for the payment of money there is no such thing as adverse possession, but the statute simply affects the remedy and not the debt.

Id. at 116 (emphasis added).

45. See, e.g., Gee v. CBS, Inc., 471 F. Supp. 600, 653 (E.D. Pa.) (holding that the running of the statute transfers valid title), affd, 612 F.2d 572 (3d Cir. 1979); Lightfoot v. Davis, 91 N.E. 582, 583 (N.Y. 1910) (same). 


\section{DeVElopments IN JUdicial MODIFICATION OF THE STATUTE OF LIMTTATIONS FOR ACTIONS TO RECOVER STOLEN ARTWORK}

In many countries, the point at which a purchaser gains rightful possession of art is easily ascertainable. ${ }^{46}$ For instance, in Japan, the law provides a two-year statute of limitations on recovery of stolen art from persons who can "plausibly claim" that they were unaware that the art was stolen when they purchased it. ${ }^{47}$ This leniency has made Japan a frequent destination for stolen art. $^{48}$ Soine European countries, mcluding Great Britain, recognize the doctrine of market overt, which allows a bona fide purchaser to acquire valid title from a thief if the sale takes place in an open market. ${ }^{49}$ Swiss law operates with the presumption that a purchaser acts in good faith and therefore can acquire good title..$^{50}$

In the United States, however, the courts have not reached a uniform conclusion on this issue. Instead, they have fashioned at least three approaches, each imposing varying burdens on the owners of stolen artwork. The differences ainong these approaches and the inconsistency with which they have been utilized leave art collectors wondering if anyone can truly assure them that they have gained rightful possession of a priceless piece of art. Thus, the courts must settle on a certain and precise approach. Only recently has such an approach begun to emerge from the alternatives.

\section{A. The Traditional Notion of Adverse Possession}

The oldest approach to determining the availability of the statute of limitations defense in an owner's replevin action derived from the concept of adverse possession. In Reynolds $v$. Bagwell, ${ }^{51}$ the Supreme Court of Oklahoma ruled that "[t]he statute of limi-

46. The international treatment of stolen artwork, although an interesting topic, is not within the scope of this Note. These examples are provided by way of contrast to the various doctrines applied in the United States.

47. Hughes, supra note 13 , at 54 .

48. Id. at 54-55.

49. JesSe Dukeminier \& JAMEs E. KRIER, Property 129 (2d ed. 1988).

50. Deborah Hoover, Museum Collections at Risk: Standards of Diligence for Protecting Your Monet, 20 J. ARTS MGMT. \& L., Spring 1990, at 47.

51. 198 P.2d 215 (Okla. 1948). 
tations as to personal property, though stolen, when held in good faith for value, openly and notoriously, runs in favor of such adverse possession so as to bar a recovery by the true owner after the expiration [of the statutory period]." 52 The operation of adverse possession helps preclude the assertion of stale claims. ${ }^{53}$

This straightforward apphication of adverse possession has several positive features. First, it focuses on the behavior of the person in possession of the stolen property and the nature of his possession. ${ }^{54}$ Second, the statutory period does not begin to run until the subsequent possessor ineets his burden of proof on the eleinents of adverse possession: $:^{55}$ (1) actual; (2) open and notorious; (3) exclusive; (4) continuous; and (5) hostile possession claimed by the party in possession as a inatter of right. ${ }^{56}$ Caselaw suggests that the proof inust be at least "clear and positive."

The doctrine of adverse possession typically favors the true owner because the possessor bears the burden of proof as to these elements. In the context of stolen art, however, the doctrine creates an almost impossible burden: either the true owner must locate the stolen property or the subsequent possessor must soinehow meet the vague requirement of "open and notorious possession," 58 a requirement intended to put the true owner on notice that his property is $\mathrm{m}$ the possession of another party. As the Supreme Court of New Jersey noted in O'Keeffe" $v$. Snyder, open

52. Id. at 216 (quoting Shelby v. Shaner, 115 P. 785 (Okla. 1911)); see BrowN, stpra note $23, \S 4.1$.

53. Charles D. Webb, Note, Whose Art Is It Anyway? Title Disputes and Resolutions in Art Theft Cases, 79 KY. L.J. 883, 886 (1990-1991).

54. Eisen, supra note 22, at 1076.

55. See, e.g., Rabinof v. United States, 329 F. Supp. 830, 842 (S.D.N.Y. 1971). In Rabinof, the 'district court refused to transfer the true owner's title to a violin to the subsequent possessor because he was unable to prove that his possession was hostile to the rights of the true owner. Id. at 843; see also San Francisco Credit Clearing House v. Wells, 239 P. 319, 321 (Cal. 1925) (finding that possession lacked continuity and openness, thereby precluding operation of adverse possession).

56. See 7 Richard R. Powell \& Patrick J. Rohan, Powell on Real ProperTY \& 1012(2) (1968); Thomas, W. Merrill, Property Rules, Liability Rules, and Adverse Possession, 79 Nw. U. L. REv. 1122, 1123 (1984-1985).

57. See Rabinof, 329 F. Supp. at $841-42$ (noting that Illinois law requires "clear, positive and unequivocal" proof); O'Keeffe v. Snyder, 405 A.2d 840, 844 (N.J. Super. Ct. App. Div. 1979) (stating that a defendant must provide proof of a "clear and positive nature" to establish adverse title), rev'd on other grounds, 416 A.2d 862 (N.J. 1980).

58. Locating stolen art is particularly troublesome; because art is so easily concealed and generally mobile, there often are significant questions as to whether possession has been open and notorious. O'Keeffe, 416 A.2d at 871 . 
and notorious use of certain types of personal property may be insufficient to serve this purpose. ${ }^{59}$ Moreover, this requirement has the effect of encouraging art theft and inaking a claim for replevin more difficult to pursue. ${ }^{60}$

\section{B. Application of the Discovery Rule in Replevin Actions}

A newer approach modifies the statute of limitations by applying the discovery rule, imported from medical malpractice cases, to a replevin action for recovery of stolen artwork, radically redistributing the burdens imposed on the respective parties and establishing a due diligence requirement. The New Jersey Supreme Court imtroduced this approach in O'Keeffe $v$. Snyder. ${ }^{61}$

The discovery rule originated in medical malpractice cases. ${ }^{62}$ In Fernandi v. Strully, ${ }^{63}$ a surgeon failed to remove a wing nut from a patient's abdomen during surgery, and the plaintiff did not discover the error for three years. The court held that "fairness and justice" dictated that the statute should not have begun to run until the plaintiff knew or had reason to know of the presence of the wing nut in her body. ${ }^{64}$

Widespread acceptance of the discovery rule has prompted its application in a variety of contexts unrelated to medical malprac-

59. Id. at 871-72. Historically, this criterion was satisfied "if the property was used as an average owner of similar property would use it," Petrovich, supra note 28 , at 1144, but traditional use of a stolen painting would not likely give notice to the true owner of the subsequent possessor's identity. Id.

In approaching this problem, the courts either had to abandon the traditional rationale of the requirement in favor of a formalistic application or require more than average use. The latter option burdens the subsequent possessor, who is then forced to go to great lengths to enjoy the property that he believes to be his own. In O'Keeffe, the court held that residential display of paintings was not sufficient to meet the statutory requirement, implying that only museum-type display would be sufficient. O'Keeffe, $405 \mathrm{~A} .2 \mathrm{~d}$ at 847 ("Display in one's home provides to the true owner no more notice of the possessor's claim ... than would its retention in a closet."). In fact, this stringent requirement of open possession may render adverse possession unworkable in replevin actions for recovery of stolen art.

60. See generally Petrovich, supra note 28, at 1147-48 (suggesting that the O'Keeffe court's interpretation of the open and notorious requirement could lead to an increase in the incidence of art theft).

61. 416 A.2d 862 (N.J. 1980).

62. See id. at 869 (citing Lopez v. Swyer, 300 A.2d 563, 566 (N.J. 1973) (stating that the discovery rule was first announced by the court in Fernandi v. Strully, 173 A.2d 277 (N.J. 1961), a medical malpractice action)).

63. 173 A.2d 277 (N.J. 1961).

64. Id. at 286. 
tice. ${ }^{65}$ In art theft cases, application of the rule suggests that the owner's cause of action will not accrue until the owner knows or reasonably should know the identity of the possessor. ${ }^{66}$ This use of the rule deviates somewhat from the traditional application, in which the action accrues when the plaintiff becomes aware of the existence of the cause of action, not merely the identity of the defendant ${ }^{67}$ At least one commentator lias suggested, lowever, that an owner of stolen art who has diligently but futilely searched for his stolen painting is not qualitatively different from a medical malpractice patient who does not yet know of his imjury, at least when compared to the traditional concept of the slothful plaintiff barred by the statute of limitations. ${ }^{68}$

1. O'Keeffe v. Snyder. The O'Keeffe case centered on the claim of noted artist Georgia O'Keeffe, who charged that the defendant, a gallery owner, was in possession of three paintings she claimed had been stolen in 1946 from a New York art gallery owned by her husband, Alfred Stieglitz. ${ }^{69}$ The defendant, Barry Snyder, claimed that he was a purchaser for value and that he liad title by adverse possession, having purchased the paintings from Ulrich A. Frank in 1975. From the time of the alleged tlieft, the paintings were displayed either in the private lome of Frank's father or in Frank's own lome. In 1975, Snyder purchased the paintings for $\$ 35,000$. O'Keeffe subsequently became aware of Snyder's possession of the paintings and commenced legal action. ${ }^{70}$ The trial court granted Snyder summary judgment on the ground that the six-year statute of limitations barred O'Keeffe's suit. The appellate court reversed, lolding that the defenses of

65. See, e.g., New Mkt. Poultry Farms, Inc. v. Fellows, 241 A.2d 633 (N.J. 1968) (holding that the discovery rule was applicable to a negligently prepared survey discovered eleven years after the initial preparation); Rosenau v. City of New Brunswick, 238 A.2d 169 (N.J. 1968) (holding that the discovery rule was applicable to defective water meter installed in plaintiff's lome).

66. O’Keeffe v. Snyder, 416 A.2d 862, 872 (N.J. 1980).

67. Petrovich, supra note 28 , at 1153 (calling the medical malpractice action the paradigm case because the plaintiff does not know he has a cause of action until the foreign object is found).

68. Id. at 1154.

69. O'Keeffe, 416 A.2d at 865.

70. See Petrovich, supra note 28 , at $1144-45$. 
adverse possession and the statute of limitations were identical and that Snyder had not proved adverse possession. ${ }^{11}$

The New Jersey Supreme Court held that adverse possession was not responsive to the needs of the art world ${ }^{72}$ and apphed the discovery rule to replevin actions for recovery of stolen artwork. Under the discovery rule, the true owner's cause of action would not accrue as long as the owner made all diligent efforts to locate the stolen property. ${ }^{73}$ With this ruling, the court attempted to vitiate the "harsh results" of mechanical application of the statute. ${ }^{74}$ By shifting the emphasis of the law to the true owner, the court hoped to discourage trafficking in stolen art and avoid leaving true owners frustrated in their efforts to recover stolen property. ${ }^{75}$ The court held that what was to constitute due diligence sufficient to toll the statute would be a question of fact $^{76}$ to be determined by weighing the equitable claims of both parties. ${ }^{77}$ The court exphicitly recognized, however, that true owners faced difficulties im trying to locate stolen art. ${ }^{78}$

71. O'Keeffe, 416 A.2d at 864-65.

72. Id. at 872. After discussing the "arcane world of sales of art, where paintings worth vast sums of money sometimes are bought without inquiry about their provenance," $i d$, the court recommended that the art world create a title registry or some other means for purchasers to discover the provenance of a painting. It then stated that "[a]though we cannot mandate the initiation of a registration system, we can develop a rule for the commencement and running of the statute of limitations that is more responsive to the needs of the art world than the doctrine of adverse possession." Id.

73. Id. While not deciding whether O'Keeffe met her burden in this case, the court did chromicle her efforts to locate the stolen paintings. Both O'Keeffe and her husband discussed the theft with their contacts in the field, although they never reported the theft to a law enforcement agency or advertised it in any art periodicals. Apparently the paintings were uninsured, and no request for reimbursement was ever made. O'Keeffe reported the paintings missing to the director of the Art Institute of Chicago but did not request that any action be taken. She also reported the theft to the Art Dealers Association of America registry of stolen paintings in 1972. In 1975, she learned the whereabouts of the paintings and promptly issued a demand for them. Id. at 866 .

74. Devereaux, supra note 24 , at 63 .

75. O'Keeffe, 416 A.2d at 872-73; Earle A. Partington \& Yves-Louis Sage, The American Response to the Recovery of Stolen and Illegally Exported Art: Should the American Courts Look to the Civil Law?, 12 Colum.-VLA J.L. \& ARTS 395, 412 (1988).

76. O'Keeffe, 416 A.2d at 873.

77. Id. at 872. The O'Keeffe case settled before a final determination on this question was ever reached. DUKEMINIER \& KRIER, supra note 49, at 127.

78. The court said that "there does not appear to be a reasonably available nethod for an owner of art to record the ownership or theft of paintings. Similarly, there are no reasonable means readily available to a purchaser to ascertain the provenance of a painting." O'Keeffe, 416 A.2d at 872. But see Hughes, supra note 13, at 54; Dourian, supra note 11. There are agencies to whoin thefts may be reported; owners are not entirely 
The O'Keeffe decision overruled precedent in New Jersey that had held adverse possession relevant to chattels, ${ }^{79}$ but it explicitly retained the notion that the running of the statute of limitations transferred title. ${ }^{80}$ This feature is an important one because without it, the possessor would have no effective ineans of receiving title once the statute had expired. Title to the property and the possessor's status would be murky at best. ${ }^{81}$

2. Autocephalous Greek-Orthodox Church of Cyprus v. Goldberg \& Feldman Fine Arts, Inc. The decision in Autocephalous Greek-Orthodox Church of Cyprus v. Goldberg \& Feldman Fine Arts, Inc. ${ }^{82}$ was a inajor victory for proponents of the discovery rule, as well as a victory (and a relief) for art museums. ${ }^{83}$ The facts of the case are as byzantine as the artifacts at issue. ${ }^{84}$ In 1988, an Indiana art dealer, Peggy Goldberg, purchased four Byzantine mosaics for just under $\$ 1.2$ million. The pieces were originally part of a large mosaic produced in 520 A.D. that was attached to the apse of the Panagia Kanakaria in a village in Northern Cyprus. The mosaics are of great historical significance because they are among the few religious icons that survived the

without means of publicizing thefts.

79. Specifically, the court overruled Redmond v. New Jersey Historical Soc'y, 28 A.2d 189 (N.J. 1942), and Joseph v. Lesnevich, 153 A.2d 349 (N.J. Super. Ct. App. Div. 1959), on this point. O'Keeffe, 416 A.2d at 873.

80. The court stated that

[b]y its terms the statute cuts off the remedy, but not the right of title ....

[T] he effect of the expiration of the statute of limitations, albeit on the theory of adverse possession, has been not only to bar an action for possession, but also to vest title in the possessor. There is no reason to change that result Id. at $873-74$.

although the discovery rule has replaced adverse possession.

81. A full discussion of this problem, ending with the author's conclusion that the New Jersey court overstated this proposition and ignored the vital function of adverse possession in title disputes, is contained in Nicholas D. Ward, The Georgia Grind Can the Common Law Accommodate the Problems of Title in the Art World, Observations on a Recent Case, 8 J.C. \& U.L. 533, 556-61 (1981-1982).

82. 717 F. Supp. 1374 (S.D. Ind. 1989), affd, 917 F.2d 278 (7th Cir. 1990), cert. denied, 112 S. Ct. 377 (1992).

83. See William H. Honan, Details of Mosaics Purchase Emerge in Indiana Trial, N.Y. TMEs, June 2, 1989, at C26.

84. A complete treatinent of the facts, as well as additional insight into the colorful personalities and intrigne surrounding this transaction, are set forth in great detail in a two-part series in The New Yorker. See Dan Hofstadter, Annals of the Antiquities Trade, The Kanakaria Mosaics Case (pts 1 \& 2), THE NEW YORKER, July 13, 1992, at 36, THE NEW YORKER, July 20, 1992, at 38. 
period of Iconoclasm in the eighth century, during which all religious art was ordered destroyed. ${ }^{85}$

When the island of Cyprus gamed independence from British rule in 1960, civil disturbances followed. In July 1974, the Turkish military invaded Cyprus from the north. Turkey established its own government for the land it claimed north of the Green Line (the Turkislı Republic of Northern Cyprus), where its troops had been stopped. The Kanakaria church is im northern Cyprus, but the military occupiers left it untouclied. However, the Greek Cypriots were eventually forced to flee to southern Cyprus, abandoning the church and its religious relics. ${ }^{86}$ Apparently, between 1976 and 1979, the Kanakaria church was vandalized. In 1979, the Cypriot Department of Antiquities received a report that the mosaics were missing; the department spent the next nine years attempting to recover thein, alerting Byzantine art authorities and others in the art community of the theft. ${ }^{87}$ In 1988 , the inosaics appeared on the nrarket.

Goldberg was im Amsterdam on business when she was offered the opportunity to view and purcliase the nosaics. Goldberg was told that the seller, Aydm Dikman, liad found the mosaics in the rubble of an "extimct" Cypriot cliurch and had been granted authority by Turkish officials to export them. She was allegedly shown export docunients establishing the authority to export the pieces. $^{88}$ After securing financing, Goldberg purchased the inosaics and returned with them to Indianapolis. ${ }^{89}$

In the fall of 1988, Goldberg offered to sell the niosaics to the Getty Museun. Meanwhile, the Cypriot anbassador had learned the mosaics were in the United States and had made inquiries in

85. The mosaics originally depicted Jesus as a young boy with his mother, seated on a throne and surrounded by hight. The mosaic was bordered by two archangels. Next to each archangel was a frieze with the busts of the twelve disciples. In time, the mosaic deteriorated; by 1960 , only Jesus, one angel, and nine disciples remained intact. Goldberg, 717 F. Supp. at 1377-78. The four mosaics Goldberg purchased included the figure of Jesus, the archangel, and the busts of James and Matthew. Meredith Van Pelt, Note, Autocephalous Greek Orthodox Church of Cyprus v. Goldberg and Feldman Fime Arts, Inc.: A Case for the Use of Civil Remedies in Effecting the Return of Stolen Art, 8 DICK. J. INT'L L. 441,443 (1990).

86. Goldberg, 917 F.2d at 280-81.

87. See Van Pelt, supra note 85 , at 444.

88. Id. at $444-45$.

89. Id. at 445 . 
an effort to locate them. ${ }^{90}$ After being contacted by Goldberg's dealers, Dr. Marion True at the museum called Dr. Vassos Karageorghis, the director of the Cypriot Department of Antiquities, who began the process by which Cyprus eventually learned of the mosaics' location in Indianapolis. After demand for possession was made and refused, the Republic of Cyprus and the Church of Cyprus filed suit. ${ }^{91}$

The court in Goldberg refused to require a claimant to commence suit during a limited period if the plaintiff had no way, even through the exercise of due diligence, to discover the existence of the cause of action..$^{92}$ However, the district court ruled that "a plaintiff who seeks protection under the discovery rule has a duty to use reasonable diligence to locate the stolen items." On review, the appellate court found that the determination of due diligence is "fact-sensitive and must be decided on a case-bycase basis"94 and elaborated on what it believed "discovering" the cause of action to encompass: "[A] plaintiff cannot be said to have 'discovered' his cause of action until he learns enough facts to form its basis, which must mclude the fact that the works are being held by another and who, or at least where, that 'other' is." ${ }^{25}$ Because it was compelled to consider the equities in tolling the statute, the district court thoroughly examined the diligence of the Cypriot government in its attempts to locate the paintings, finally deciding that the government's efforts were sufficient to satisfy the due diligence requirement. ${ }^{96}$

90. Id.

91. Autocephalous Greek-Orthodox Church of Cyprus v. Goldberg \& Feldman Fine Arts, Inc., 917 F.2d 278, 283-84 (7th Cir. 1990), cert. denied, 112 S. Ct. 377 (1992).

92. See id.

93. Autocephalous Greek-Orthodox Church of Cyprus v. Goldberg \& Feldman Fime Arts, Inc., 717 F. Supp. 1374, 1389 (S.D. Ind. 1989), affd, 917 F.2d 278 (7th Cir. 1990), cert denied, 112 S. Ct. 377 (1992) (citation omitted). In fact, the appellate court stated that the district court judge hearing the case found the true owner's exercise of due diligence a "necessary precondition" to application of the discovery rule. Goldberg, 917 F.2d at 289. Cyprus was not and could not reasonably have been on notice of the mosaics' location until 1988, when they surfaced in Indianapolis. Id.

94. Goldberg, 917 F.2d at 289 (quoting Goldberg, 717 F. Supp. at 1389).

95. Id. (citing O'Keeffe v. Snyder, 416 A.2d 862, 869-70 (N.J. 1980)).

96. Goldberg, 717 F. Supp. at 1389. From the time it learned of the theft, the government of Cyprus engaged in a methodical and thorough effort to recover the lost property. It first contacted the United Nations Educational, Scientific and Cultural Organization (UNESCO) to seek assistance in recovering the lost mosaics. News of the theft was spread to several international organizations and officials whom the Cypriot governnent beheved could assist in locating the pieces, including the International Council of 
The successful efforts of the Cypriot government could serve as a model, at least for institutional collectors, of the effort necessary to meet the due diligence requirement under the discovery rule. On the other hand, it seems unrealistic to expect individuals to have the resources necessary to engage in such a massive and painstaking search. What might be inost appropriate to conclude from this application of the discovery rule, then, is that by its steady search efforts, Cyprus made its mission abundantly clear to everyone im the art, pohtical, and academic communities-the government aimed to notify everyone of the theft and let it be known that it was actively seeking the return of the missing pieces. The unequivocality of the Cypriot government's attempts to recover the mosaics may have been the inost persuasive element in the court's determination of due diligence.

In Goldberg, the court found it unnecessary to inquire into the buyer's status as a bona fide purchaser. ${ }^{97}$ However, this analysis may have overlooked a significant feature of Indiana law and produced a decision that clouded the rights of the parties more than is readily apparent. In its decision, the Goldberg court failed to apply the state requirement that a demand be made for possession before suit can be filed against an innocent, or bona fide, purchaser. ${ }^{98}$ When demand is required, the limitations period for actions agamst the innocent purchaser does not begin to run until there has been a demand for possession and a subsequent refusal to return the property. ${ }^{99}$

Museums and Sites and Harvard University's Dumbarton Oaks Institute for Byzantine Studies. All possible attempts at publicizing the thefts were undertaken, including release of regular notices to American and imternational journalists, elected officials, scholars, and authorities, updating them on the situation. Id. at 1380. Some skeptics have uoted, however, the oddity that Cyprus did not put any detectives on the case and did not notify Interpol or the customs agents of any nation. Hofstadter, pt. 1, supra note 84, at 51 .

After deciding that Cyprus had met its burden of due diligence, the court concluded that the cause of action did not accrue until 1988, when the church learned the location of the mosaics and that therefore the suit was filed within the statutory period. Goldberg, 717 F. Supp. at 1391.

97. Id. at 1399 n.22 ("Under Indiana law, even a bona fide purchaser cannot acquire title to or right to possession of stolen property."). Because the court found that the nosaics were stolen, Goldberg's status as a bona fide purchaser would not have made a difference in the resolution of the suit.

98. In Wood v. Colien, 6 Ind. 455 (1855), the Supreme Court of Indiaua noted that a thief would be hable when the goods were converted, but a demand for possession was necessary to initiate suit against an innocent purchaser. $I d$. at 456.

99. But see Jones v. Sunith, 24 N.E. 368 (Ind. 1890) (stating that there is no require- 
The court's omission is not an esoteric one; it has at least two consequences. First, under the demand rule, the state affords some protection to innocent purchasers: they are made aware of any claim against them and are given the opportunity to surrender possession of stolen goods before becoming subject to suit. Similar protection is not given to purchasers who know that a piece is stolen (i.e., those who are not bona fide purchasers). ${ }^{100} \mathrm{~A}$ determination that status as a bona fide purchaser is irrelevant to the accrual of the cause of action removes the protection previously offered to innocent purchasers. Such a purchaser, therefore, can be subjected to suit despite his ignorance of a controversy. Second, the due diligence requirement produces converse results depending on whether a demand is necessary. If no demand is necessary, as the court found in this case, the true owner's time to file suit is extended for the period during which it uses diligent efforts to locate the property. Under these circunistances, the due diligence requirement acts as an expansionary force. On the other hand, if a demand is necessary, the due diligence requirement limits the time the owner has to file suit. Without the requirement of diligence, the owner is under no obligation to search for the stolen property but can wait to fortuitously discover its whereabouts before making a demand. ${ }^{101}$

The discovery rule has now become the majority rule in replevin actions for recovery of stolen art, followed in almost every .jurisdiction. ${ }^{102}$ New York is a notable exception. ${ }^{103}$

3. Benefits of and Difficulties with the Discovery Rule. Because the discovery rule involves a case-specific standard, its application can lead to inconsistent decisions, ${ }^{104}$ although its

ment of a demand when the thief has obtained possession by wrongful or fraudulent means); Parrish v. Thurston, 87 Ind. 437 (1882) (same).

100. See Foutty, supra note 18 , at 1854.

101. See id. at 1857-58.

102. State Bar Committee on Legal Aspects of the Arts, Acquiring Title to Stolen Art, 55 TEX. BAR J., March 1992, at 237, 238.

103. See infra text accompanying notes 131-34.

104. Compare DeWeerth v. Baldinger, 658 F. Supp. 688 (S.D.N.Y.) (finding that individual owner failed to meet burden), rev'd, 836 F.2d 103 (2d Cir. 1987), cert. denied, 486 U.S. 1056 (1988) with Autocephalous Greek-Orthodox Church of Cyprus v. Goldberg \& Feldman Fine Arts, Inc., 717 F. Supp. 1374 (S.D. Ind.) (finding that Cypriot nation, as owner of ancient relics, met burden of diligence), aff $d, 917$ F.2d 278 (7th Cir. 1990), cert. denied, 112 S. Ct. 377 (1992). Some commentators have suggested that divergent standards should emerge to distinguish between efforts required of individuals and those 
purpose is to clarify the obligations of the true owner. ${ }^{105}$ Whether the value of this clarification overcomes the disadvantage of inconsistent standards is debatable. One author has suggested that if a due diligence requirement is to be applied uniformly, a plaintiff should be compared only to a "similarly situated reasonably prudent person" and that courts should specifically note the difference in resources between individual and institutional collectors in applying the rule. ${ }^{106}$

Another basis for inconsistency is the lack of a umified approach to the reporting of stolen art. There is, in fact, no single way to alert the community of a theft. Because pohice efforts vary by jurisdiction, there is no uniform method to evaluate whether the true owner undertook reasonable investigative effort. Courts nay experience difficulty extrapolating from one case to another im determining whether an investigation reaches the level of due diligence. Because of this difficulty, true owners' obligations are not in fact clarified. ${ }^{107}$ Moreover, an owner may overcompensate for uncertaimty by taking any nuniber of potentially unnecessary and excessive measures. In the end, the inherent uncertainty of this protection may force the true owner into a choice between taking steps to fulfill the duty of diligence or forgoing the costly measures and conceding ownership of the piece. ${ }^{108}$

One apparent advantage of the rule, on the other hand, is that it seems to meet the stated purpose of the statute of limitations-to punish unreasonable delay by a person with a claim to pursue, thereby protecting the defendant from having to defend against a stale claim. ${ }^{109}$ This benefit is illusory, however. The

required of institutions. See Sydney M. Drum, DeWeerth v. Baldinger: Making New York a Haven for Stolen Art, 64 N.Y.U. L. REV. 909, 938 (1989) (suggesting inconsistency may result from applying a uniform standard despite distinctions between individual and institutional owners).

105. This is of limited benefit because the discovery rule is not uniformly adopted across the country. Because the owner cannot anticipate in what jurisdiction the painting may appear or what his obligations might be under that jurisdiction's laws, this inatter is left somewhat unresolved.

106. Drum, supra note 104 , at 938 . Institutional collectors, generally museums, have financial resources far greater than those of most private collectors. They also have access to trained persomel and contacts in the art world, which allow them to take advantage of a greater networking effect to alert the art community of a theft. See id. at 939-41.

107. Id. at 941.

108. Eisen, supra note 22, at 1067.

109. See Foutty, supra note 18 , at 1860 ("By adopting the due diligence requirement 
O'Keeffe court made clear that application of the discovery rule was intended to favor the true owner, announcing that it was creating a rule "more responsive to the needs of the art world."110 It accomplished this result by allowing the owner to extend the limitations period through diligent efforts to locate a stolen painting.

An often-espoused criticism of the application of the discovery rule in this context is that the court focuses solely on the actions of the true owner, not on the elements of adverse possession or on the subsequent possessor's burden. Abandoning any requirements for the subsequent possessor's use and possession of the property gives him no imcentive to reveal possession of the property im any way. On the contrary, the mcentive is to hide the piece because a public showing miglit facilitate the owner's location of the lost piece. ${ }^{111}$ The discovery rule's singular focus on the true owner makes the purchaser's actions, assuming he is im fact unaware that the painting has been stolen, largely irrelevant. ${ }^{112}$

If, as the O'Keeffe court noted, application of the discovery rule is intended to miport equity into the statute of himitations, ${ }^{113}$ the rule fails to consider the equities to the purchaser. In most cases, the person in possession of the stolen artwork has no knowledge of the true owner's attempts to locate the missing piece. Presumably, if the person in possession acquired such knowledge, it would affect his status as a good faitl possessor, precluding the assumption of title once the statute has run. In the end, then, whether the subsequent possessor may enjoy rights to

courts send an effective message to owners of stolen art: the right to maintain a recovery action is circumscribed by the duty to act prudently."). But see Drum, supra note 104, at 937 (suggesting that a "more generous statute of limitations" for owners would be more in keeping with the traditional balance struck in other types of cases in which the plaintiff brings suit after the literal statutory period has run. Given the obstacles plaintiffs face in art cases, the time limitation should be a broad one).

110. O'Keeffe v. Snyder, 416 A.2d 862, 872 (N.J. 1980).

111. As one commentator has suggested,

A rule that hinders the ability of original owners to recover stolen art works provides economic incentive for thieves to steal and for art dealers to remain silent as to the illicit origins of a stolen work. Such a rule encourages the appropriation ... of great works of art, and is, therefore, in direct opposition to the public interest.

Drum, supra note 104, at 933-34 (citation omitted).

112. For a discussion reaching the opposite conclusion, see Van Pelt, supra note 85, at 460 (concluding that because the rule will encourage an owner to follow all avenues' to locate a painting, a buyer will be wary of items in which loe is interested).

113. O'Keeffe, 416 A.2d at 872. 
the painting that he beheves to be his own depends solely on the actions of another, anonymous person. Moreover, there is no teinporal limitation on the subsequent possessor's hability; he may remain subject to suit for any number of years after acquisition of the property.

A notable objection to the apphication of the discovery rule is that it conflicts with the common law notion that a bona fide purchaser of personal property that is taken tortiously or wrongfully, as by trespass or theft, does not acquire title good against the true owner. ${ }^{114}$ The Uniform Commercial Code (UCC) codifies the common law axiom. ${ }^{115}$ Following this logic, it seems that between the true owner and a subsequent bona fide purchaser, the true owner should be entitled to the goods because the thief had no title to convey to the subsequent possessor. ${ }^{116}$ In the context of stolen artwork, however, the courts have given this subject only cursory treatinent. In O'Keeffe, for example, the court made no mention of the effect of the theft of the paintings on the purchaser's eventual right to gain title. ${ }^{117}$ Because the purchaser has no right to the artwork, it seeins anomalous to allow the statute of limitations to prevent the true owner from bringing suit inerely because he has failed to take affirmative actions. ${ }^{118}$

114. South Miss. Fin. Co. v. Mississippi State Tax Comm'n, 605 So. 2d 736, 739 (Miss. 1992) (noting that this rule is "as old as the hills and often enforced without regard to context, viz., no thief . . . has power to pass title to his ill-gotten goods") (citations omitted).

115. See U.C.C. \& 1-201(32) (1989) (defining "purchase" as a voluntary transfer creating an interest in property); id. § 2-403(1) (providing that a purchaser of goods has only the title his transferor had power to transfer).

116. See, e.g., Porter v. Wertz, 416 N.Y.S.2d 254, 259 (App. Div. 1979), affd, 439 N.Y.S.2d 105 (N.Y. 1981) (citation omitted) (stating that "[p]ossession without more is insufficient to create an estoppel" and holding that the true owner of an Utrillo was entitled to the return of the painting or danages from its loss from the subsequent possessor, who obtained the painting from a person not authorized to sell it); Lieber v. Mohawk Arms, Inc., 314 N.Y.S.2d 510, 512 (Sup. Ct. 1970) (holding that owner of Hitler's personal belongings was entitled to recover the items that the transferor stole from him and sold to a bona fide purchaser).

117. O'Keeffe, 416 A.2d at 873. In Goldberg, the court failed to take notice of this issue. Autocephalous Greek-Orthodox Church of Cyprus v. Goldberg \& Feldman Fine Arts, Inc., 917 F.2d 278 (7th Cir. 1990), cert. denied, 112 S. Ct. 377 (1992).

118. See Eisen, supra note 22 , at 1100 (arguing that denying the owner his right to sue fails to achieve the discovery rule's ain of equity). 


\section{The Demand Rule as a Prerequisite for Accrual}

Not all courts have been willing to adopt the discovery rule. Another approach to the determination of accrual is to use the demand rule, a judicial doctrine reinterpreting the statute of limitations. The rule, which normally applies in actions to recover chattel, requires that the true owner make a demand for possession and that the possessor refuse to release the property in order to start the statute of limitations running. ${ }^{119} \mathrm{~A}$ minority of state courts, most notably New York, takes this approach. ${ }^{120}$

1. Menzel v. List. In Menzel v. List, ${ }^{121}$ the New York Court of Appeals considered the question of accrual in a suit to recover a stolen painting. The plaintiffs sought to recover a gouache by Marc Chagall that they had been forced to leave hangimg in their apartment when they fled the Nazis in 1941. The Nazis confiscated the painting and left a receipt showing it had been taken for "safekeeping." The Menzels relocated to the United States in 1941, and although they searclied for the painting, they were unable to locate it until it was found in the possession of the defendant, Albert List, in November 1962. ${ }^{122}$ List claimed lie purchased the painting in good faith from a gallery in New York in 1955. The whereabouts of the painting from 1941 until 1955 were never established, but the gallery owner from whom List purchased the painting claimed to have bouglit it from the reputable Galerie Art Moderne in Paris. ${ }^{123}$

Both sides agreed that List was an innocent purcliaser who had no knowledge that the painting was stolen when he acquired it. List claimed that the statute of limitations barred the suit, based on the running of the statute either from the date the painting was originally stolen in 1942 , or from the time his possession began in $1955 .{ }^{124}$ The court denied this defense, however: "In replevin ... the cause of action against a person who lawfully comes by a chattel arises, not upon the stealing or the taking, but upon the defendant's refusal to convey the chattel upon de-

119. See Solomon R. Guggenheim Found. v. Lubell, 569 N.E.2d 426, 429 (N.Y. 1991).

120. See id.

121. 246 N.E.2d 742 (N.Y. 1969).

122. Menzel v. List, 267 N.Y.S.2d 804, 806-07 (Sup. Ct. 1966), modified, 279 N.Y.S.2d 608 (App. Div. 1967), rev'd, 246 N.E.2d 742 (N.Y. 1969).

123. Id. at 807-08.

124. Petrovich, supra note 28 , at 1134. 
mand." $" 125$ Even a twenty-year lapse of time between the commencement of proceedings and the defendant's initial possession did not bar the suit.

In making its decision on the statute of limitations defense, the court cited earlier decisions im which it had explained that demand and refusal are prerequisites to a cause of action for conversion. This requirement makes the imnocent purchaser aware that a claim against the property is pending and offers an opportumity to return the property before being treated as a wrongdoer. Until the owner makes a demand and the subsequent possessor refuses to surrender the property, the possession is not considered wrongful. ${ }^{126}$ The subsequent possessor, having acquired the property by honest and lawful means, has no reason to suspect a claim until a demand is made. ${ }^{127}$ This treatment of the innocent purchaser is consistent in theory with the treatment of a person in possession of goods that he knows to be stolen, a "wrongful possessor." In those cases, the courts treat the wrongful possessor as having the requisite warning that a claim agamst the property is pending and therefore dispense with the requirements of demand and refusal. ${ }^{128}$ Similarly, the innocent purchaser has statutory protection until lie learns that his possession is wrongful through a demand by the true owner.

2. Kunstsammlungen zu Weimar v. Elicofon. Further development of the demand rule emerged from the decision in Kunstsammlungen $z u$ Weimar v. Elicofon, ${ }^{129}$ im which a federal district court interpreted New York law regarding the recovery of stolen art. The case involved two Albrecht Duerer paintimgs exhib-

125. Menzel, 267 N.Y.S.2d at 809 (citations omitted).

126. Kunstsammlungen zu Weimar v. Elicofon, 536 F. Supp. 829, $848-49$ (E.D.N.Y. 1981), affd, 678 F.2d 1150 (2d Cir. 1982).

127. The Indiana Supreme Court interpreted the demand rule fashioned in its state courts in the following manner:

This rule is based on the presumption which the law indulges that one wlo has lawfully come into possession of property which he is not entitled to retain will, upon demand, surrender it to the person entitled thereto and that he ought to be afforded an opportumity so to do without being subjected to the inconvenience and expense of a law suit.

Butler v. Wolf Sussman, Inc., 46 N.E.2d 243, 244 (Ind. 1943) (citations omitted).

128. See Atlas Ins. Co. v. Gibbs, 183 A. 690, 692 (Conn. 1936) (noting that demand is not necessary when the possession is a result of the possessor's wrongful taking, wrongful use, or wrongful exercise of control over the property).

129. 536 F. Supp. 829 (E.D.N.Y. 1981), affd, 678 F.2d 1150 (2d Cir. 1982). 
ited by a German art museum, Kunstsammlungen zu Weimar. During World War II, the paintings were housed for safekeeping in a castle, the Schloss Schwarzburg, located in what became East Germany. They were stolen from the castle in 1945. In 1966, they were located in the hoine of Edward Ehcofon, where they had been displayed since he purchased thein almost twenty years earlier. The case involved inyriad international and dynastic law questions, due largely to the intervention of the Grand Duchess of Saxony-Weimar, who made a claim to the paintings. ${ }^{130}$

The district court, in a decision that was affirmed by the U.S. Court of Appeals for the Second Circuit, interpreted New York's law to require a demand and refusal to start the statute of limitations running. The only requirennent the court specified was a deinand for possession followed by a refusal to surrender the property. ${ }^{131}$ The court declimed to impose a requirement of due

130. Elicofon, 678 F.2d at 1153-55. The Grand Duchess intervened as a plaintiff, arguing that the paintings had been the private property of the successive Grand Dukes of Saxony-Weimar and that title to the paintings bad been passed to her by her husband, Grand Duke Carl August. The inuseum, representing the claim of the East German government, asserted that title to the painting passed to East Germany as the successor in interest to the prior regime's property.

131. New York law provides that when a demand is necessary to commence an action, the action accrues at "the time when the right to make the demand is complete." N.Y. CIV. PRAC. L. \& R. § 206(a) (McKinney 1990). In Federal Ins. Co. v. Fries, 355 N.Y.S.2d 741, 747 (Civ. Ct. 1974), the court interpreted this section as holding that a right to demand possession of property is complete when the defendant acquires the property, regardless of whether the plaintiff knows all the facts. However, the courts have distinguished between the statute's application as a procedural element and as a substantive element. The statute applies only when the deinand is a procedural element in the cause of action. In Menzel v. List, 253 N.Y.S.2d 43, 44 (App. Div. 1964), the appellate court held that "with respect to a bona fide purchaser of personal property a deinand by the rightful owner is a substantive ... prerequisite to the bringing of an action." This rule, dubbed the "unreasonable delay" rule, starts the statutory period running when the plaintiff has had the opportunity to locate the property and inake a demand and has failed to do so. DeWeerth v. Baldinger, 836 F.2d 103, 107 n.4 (2d Cir. 1987), cert. denied, 486 U.S. 1056 (1988); see also, e.g., Elicofon, 678 F.2d at 1161 (holding section 206 inapplicable in actions seeking recovery from an innocent purchaser).

There has been some attention given to whether the requirement of demand is indeed a substantive requirement for a replevin action. In Atlas, the defendants, innocent purchasers of a stolen autonobile, claimed the action in replevin was improperly filed because no demand was made. The court said that although innocent purchasers are usually entitled to a demand, it is not an element of a replevin case but merely a protection. Atlas, 183 A. at 693. If the defendant is not seriously injured by its absence, courts may not require a demand, even in cases involving purchasers of stolen property. However, this does not seem to be a matter subject to question in New York; inoreover, it is imconsistent with the courts' treatment of wrongful possessors, who are not accorded the protection of a deinand, and against whom the statute begurs to run immediately. 
diligence because it found that the true owner had made diligent efforts. ${ }^{132}$ However, the court warned that there was an implicit requirement that the plaintiff not unreasonably delay in inaking a demand once the property was located. ${ }^{133}$ Presumably, it recognized this requirement to prevent plaintiffs from making unreasonable delays in pursuing their clains. ${ }^{134}$ The Second Circuit reviewed the inuseum's efforts to report the theft and to locate the stolen pieces, ${ }^{135}$ concluding that the inuseum had shown the requisite diligence in making the demand. ${ }^{136}$ Narrowly interpreting the decision in Menzel $v$. List, however, the court reiterated that due diligence in investigating the claim was not a requirement under New York law. ${ }^{137}$

In Elicofon, the plaintiff argued that without a requirement that the true owner exercise due diligence in searching for a stolen piece, the demand rule favors the thief over the bona fide purchaser. ${ }^{138}$ The statute of limitations begins to run against a thief immediately, but a bona fide purchaser inust wait indefinitely for demand to be made before the statute begins to run. ${ }^{139}$ The plaintiff further argued that because under the statute, the bad faith purchaser is treated identically to the thief, the statute, also

132. Elicofon, 536 F.Supp. at $849-50$.

133. Id. at 849 (citing Heide v. Glidden Buick Corp., 67 N.Y.S.2d 905, 906 (App. Term 1947)); see also Reid v. Board of Supervisors, 28 N.E. 367,369 (N.Y. 1891) (providing that when a plaintiff demands possession of property, the demand must be made within a reasonable period of time); Heide, 67 N.Y.S.2d at 906 (holding that a true owner may not postpone demand indefinitely but must make demand within a reasonable time).

In DeWeerth, the court clarified that this proscription against unreasonable delay is not coterminous with laches, although it sounds similar. It refers only to an unexcused lapse of time, not to injury to the defendant, as laches requires. DeWeerth, $836 \mathrm{~F} .2 \mathrm{~d}$ at 107.

134. See generally Webb, supra note 53 , at 888 .

135. Elicofon, 678 F.2d at 1156 . In reviewing the museum's actious, the court noted that the director had contacted various museums and administrative organizations to report the theft, including the Allied Control Council, the Fogg and Germanic Museums at Harvard University, the U.S. State Department, and the Soviet Military Administration. Elicofon's discovery in 1966 that the paintings were authentic Duerers nuade world news. Thereafter, the nuuseum demanded possession of the paintings. Id. at 1156.

136. Id. at $\mathbf{1 1 6 5}$ (affirming the district court's conclusion that the nnuseum had shown diligence in making its demand).

137. See Menzel v. List, 267 N.Y.S.2d 804 (Sup. Ct. 1966), modified, 279 N.Y.S.2d 608

(App. Div. 1967), rev'd, 246 N.E.2d 742 (N.Y. 1969).

138. Kunstsammlungen zu Weimar v. Elicofon, 678 F.2d 1150, 1163 (2d Cir. 1982).

139. Id. 
favors a bad faith purchaser over the bona fide purchaser. ${ }^{140}$ In response to this argument, the court cited the decision of the New York Court of Appeals in General Stencils, Inc. v. Chiappa, ${ }^{141}$ which states that the operation of equitable principles prevents such anomalous favoring of the thief. ${ }^{142}$ Moreover, the court noted that New York had consistently favored protection of the true owner's rights and had not allowed the limitations period to run regardless of the owner's ignorance. ${ }^{143}$ This discussion was the backdrop for the next significant case interpreting New York's demand rule. It came as the first sign from the courts that the perceived lack of balance in the equities might be a source of concern.

3. DeWeerth v. Baldinger. In 1987, in DeWeerth $v$. Baldinger, ${ }^{144}$ the U.S. Court of Appeals for the Second Circuit, applying New York law, modified the demand rule to include a requirement of due diligence im searching for a stolen painting. ${ }^{145}$ It thereby squarely focused attention on the equities in replevin actions for recovery of stolen art.

In 1922, the plaintiff, Gerda DeWeerth, inherited a Monet painting entitled Champs de Blé à Vétheuil. The painting hung in her home between 1922 and 1943. Once the collapse of the German Third Reich was imminent, DeWeerth relocated, sending the painting to her sister in southern Gerinany for safekeeping. In 1945, shortly after the end of World War II, American soldiers were stationed in the castle in which DeWeerth's sister hived. Thereafter, the sister noticed that the painting was missing. ${ }^{146}$

140. Id. (citing Gillet v. Roberts, 57 N.Y. 28 (1874)).

141. 219 N.E.2d 169 (N.Y. 1966).

142. In Chiappa, the court held that equitable estoppel prevents the wrongdoer from asserting the statute of limitations as a defense so he cannot "take refuge behind the shield of his own wrong." Id. at 170-71. The Elicofon court noted that even if the principles of equity did not prevent this anomaly, the bona fide purchaser is still treated better than the thief in that he is not responsible for damages to the property prior to the demand. Elicofon, 678 F.2d at 1163 n.24 (citations onitted).

143. Elicofon, 678 F.2d at 1163-64.

144. 836 F.2d 103 (2d Cir. 1987), cert. denied, 486 U.S. 1056 (1988).

145. Id. at 109-10. After the New York Court of Appeals decision in Guggenheim, which effectively overruled the decision in this case, the district court granted relief to the plaintiff under FED. R. Crv. P. 60(b), enabling her to retain ownership and possession of the painting. DeWeerth v. Baldinger, 804 F. Supp. 539, 555 (S.D.N.Y. 1992). For a discussion of Guggenheim, see infra Part III.

146. DeWeerth, 836 F.2d at 104-05. 
After learning of the disappearance, DeWeerth contacted several authorities to report the loss. In 1946, she filed a report with the military government managing the northern provinces of Germany; in 1948, she wrote a letter to an attorney asking if any steps could be taken to obtaim the return of the painting. DeWeerth also sent a picture of the painting to a renowned art professor, asking him to investigate the location of the painting. Finally, in 1957, almost 12 years later, she reported the theft to the West German Bureau of Investigation in a hist of items she lost during the war. No evidence indicates that any of these efforts were fruitful, and they were the last significant efforts DeWeerth undertook to locate the painting. ${ }^{147}$

The Monet resurfaced in December 1956, when a New York City art gallery obtained it from Francois Reichenbach, a Swiss art dealer. The painting was then purchased by Edith Baldinger for $\$ 30,900$. Neither party disputed that Baldinger was an innocent purchaser. With the exception of two public exhibitions in 1957 and 1970, the painting hung in Baldinger's hoine until one of DeWeertli's nephews located it. DeWeerth subsequently made a demand for possession. ${ }^{148}$

Baldinger asserted the statute of limitations as a defense, as well as laches, claimed an unreasonable delay in the commencement of proceedings, and pressed for the adoption of the "due diligence" rule utilized in other jurisdictions. DeWeerth claimed there could be no unreasonable delay when she could not ascertain the identity of the present possessor and could not know against whom the claim was to be made. ${ }^{149}$

The district court ruled that the demand rule required no more than that DeWeerth file suit within three years of the demand and refusal. Under this standard, the delay in brimging suit was reasonable, and the suit was timely filed. ${ }^{150}$ The Second Circuit, however, ruled that in addition to the obligation to make a demand witlout delay once the person im possession of the property is identified, the true owner has an obligation to undertake diligent efforts to locate the stolen property to make a demand in

147. Id. at 105 .

148. Id. at $105-06$.

149. Devereaux, supra note 24 , at 60 .

150. DeWeerth v. Baldinger, 658 F. Supp. 688, 694 (S.D.N.Y.), rev'd, 836 F.2d 103 (2d Cir. 1987), cert. denied, 486 U.S. 1056 (1988). 
a timely manner. The court found DeWeerth's minimal investigation insufficient to constitute such an effort. ${ }^{151}$ In doing so, the court compared DeWeerth's individual efforts to the museun's efforts in Elicofon; ${ }^{152}$ although the court purported to decide the case on equitable standards, ${ }^{153}$ it gave no more than a glancing concern to any inequity in that comparison.

The DeWeerth court found that the inquiry into diligence necessarily had to focus on DeWeerth's efforts, rather than Baldimger's actions, ${ }^{154}$ in order to accord with what the court called New York's pohicy of protecting innocent purchasers. ${ }^{155}$ It pointed out that without a due diligence requirement, a good faith purchaser could be exposed to suit long after a thief or wrongful possessor would have achieved repose. Yet, as others have observed, the court's assertion all but ignores the rule im Menzel $v$. List that an innocent purchaser suffers no legal exposure until he has been made aware of a pending claim. ${ }^{156}$ The statutory period is no longer for the innocent purchaser than the thief because in the eyes of the law, the possession is not wrongful until demand is inade, and it is only on demand that the statutory period begins to run. ${ }^{157}$

151. DeWeerth, 836 F.2d at 111-12.

152. The court reviewed DeWeerth's efforts, comparing her investigation to that of the museum in Kunstsammlungen zu Weimar v. Elicofon, 536 F. Supp. 829 (E.D.N.Y. 1981), affd, 678 F.2d 1150 (2d Cir. 1982), see supra note 135, and found DeWeerth's failure to contact several agencies established for the purpose of locating stolen art particularly notable. For example, DeWeerth failed to notify the U.S. State Departınent, which was actively engaged in locating stolen art, and the allied forces' program in Europe, which was established for the same purpose and through which her family had recovered other stolen pieces. Also, DeWeerth neglected to contact museums and galleries whose vigilance might have been helpful. Finally, the court said that DeWeerth's failure to search for 27 years, between 1957 and 1981, was a significant ounission, because during that time there were several references to the painting in publications. Indeed, it was a listing in the Catalogue Raisonne through which she eventually located the painting. DeWeerth was a sophisticated art collector, the court said, and she could have hired someone to conduct an investigation even if she were unable, because of her age, to conduct the search herself. DeWeerth, $836 \mathrm{~F} .2 \mathrm{~d}$ at 111-12.

153. This comparison is in stark contrast to the district court's assessment of DeWeerth's efforts as reasonable. The district court found her endeavors "fruitless" but credited her for her effort. In addition, the district court noted that she was, at this point, an elderly woman, lacking the resources and contacts that an institution would have. DeWeerth, 658 F. Supp. at 694-95.

154. See DeWeerth, 836 F.2d at 109.

155. Id. at 108.

156. See Drunn, supra note 104, at 931 .

157. See Menzel v. List, 267 N.Y.S.2d 804, 809 (Sup. Ct. 1966), modified, 279 N.Y.S.2d 
The court found that applying a due diligence rule to stolen art was particularly appropriate because art is generally housed in private collections, making it likely that an owner looking for a piece would learn of its location only through investigation. The due diligence requirement, the court said, gives the owner incentive to search for his property by barring a later claim of ownership if he does not. ${ }^{158}$ The court noted that a further advantage of the rule is that because art loses value when damaged or altered, a true owner recovering the property is more likely than other victims to find his property in its original condition, thus making the true owner's diligence more worthwhile. ${ }^{159}$ However, these observations overlook the fact that much of the art that is recovered is located only after a fortuitous chain of events leads to the identification of the present location of the piece. A recovery rate of around ten percent indicates that recovery is not the coinmon result of diligent efforts. ${ }^{160}$ In essence, the requirement of diligence may serve as an econoumic incentive for thieves. By deinanding that a true owner undertake a diligent search and incur a panoply of financial, einotional, and logistical strains, this rule effectively hinders the true owner in attempting to recover stolen pieces and makes the thief's continued possession more likely. ${ }^{161}$

The court stated that the purpose of statutes of limitations was to proinote "fairness to a defendant."162 The imposition of the due diligence requirement, it said, is appropriate in art theft cases because of the long delays in locating stolen artwork. Without such a requirement, no legal obhigation to pursue a claim arises, and the goal of fairness would be thwarted by making imiocent purchasers and their heirs subject to suit for centuries. True owners would be free to unreasonably delay actions until the location of the property was fortuitously discovered, and fraudulent

608 (App. Div. 1967), rev'd, 246 N.E.2d 742 (N.Y. 1969).

158. DeWeerth, 836 F.2d at 109-110 (citing O'Keeffe v. Snyder, 416 A.2d 862 (N.J. 1980)).

159. See id. at 109.

160. See Drum, supra note 104, at 933 (discussing further how art dealers' lack of diligence $\mathrm{m}$ authenticating the provenance of artwork contributes to the problem of international art theft).

161. Id. at 933-34.

162. DeWeerth, 836 F.2d at 109 (citing Flanagan v. Mount Eden Gen. Hosp., 248 N.E.2d 871 (N.Y. 1969)). 
claims would be encouraged to the extent that memories had faded and evidence had been lost. ${ }^{163}$

However, this view fails to recognize the protection that New York's Menzel rule affords owners. Like other modifications to the mechanical operation of the statute of limitations period, the demand rule is intended to give plaintiffs the benefit of time. In stolen art cases, the rule represents an imphicit judicial recognition of the difficulties true owners face in locating stolen art and a policy choice favoring the true owner over the innocent purchaser. This idea is consistent with traditional notions of equity because if the statute began to run against the true owner at the time of the theft, without allowing the owner time to locate the artwork, the owner would be left without a reinedy once the statutory period ended.

By contrast, even if a true owner wins a suit for replevin, an innocent purchaser may still seek a remedy from the person from whoin he purchased the work. For example, he might institute a suit aganist his seller for breach of warranty. ${ }^{164}$ In addition, although the innocent purchaser may lose the defense of the statute of limitations by operation of the demand rule, he is free to assert a claim of laches. The availability of laches as a defense is inportant; it answers the court's concern that innocent purchasers may be subject to suit years, or even centuries, after acquisition of property because no legal obhigation to pursue the claim has arisen. Such a delay would certainly injure purchasers who could not defend against replevin suits because of lost evidence and faded memories without incurring higher costs than would have been incurred if owners were required to make a prompt demand. ${ }^{165}$

In rendering its decision, the DeWeerth court squarely faced the demand rule's anomalous difference in treatinent between thieves and imiocent purchasers. The court reasoned that without a requirement of due diligence, the thief was in a more enviable position than the innocent purchaser because as long as no demand was inade against the purchaser, the statutory period did not accrue, and the purchaser reinained subject to suit. The court's requirement of diligence helped mitigate the inequity of favoring

163. See id.

164. See Drum supra note 104 , at 938.

165. Id. at $942-43$. 
the thief over the innocent purchaser and created an incentive for the plaintiff to search for the painting. ${ }^{166}$

The Second Circuit refused to certify the question to the New York Court of Appeals on the ground that the problein was not likely to recur with sufficient frequency to require a determination by that court. As the New York Court of Appeals observed in a later case, however, the courts do face this question with surprising frequency. ${ }^{167}$

\section{SOLOMON R. GUGGENHEIM FOUNDATION V. LUBELL AND ITS IMPLICATIONS}

Following the DeWeerth case, the due diligence standard, in conjunction with the deinand rule, seemed firmly entrenched. In its 1991 decision in Solomon R. Guggenheim Foundation $v$. Lubell, ${ }^{168}$ however, the New York Court of Appeals retrenched and returned the law of New York to the deinand and refusal standard, abandoning the due diligence requirement the Second Circuit had imposed in DeWeerth.

\section{A. The Decision in Guggenheim}

As in earlier cases, the Guggenheim decision involved a stolen painting and the question of when the rights of the true owner to sue for return of the painting were lost by the passage of time. The case involved a gouache by Marc Chagall, Menageries or Le Marchand de Bestiaux, valued at around $\$ 200,000$. The Guggenheim Museum sued the defendants for return of the painting after discovering its whereabouts in 1986, over ten years after the museum had written off the painting as lost. The inuseum discovered the painting was misplaced some time in the 1960 s but did not admit that it was unissing until a comprehensive inventory in 1970. Having discovered the loss, the Guggenheim failed to notify any other museums, the police, Interpol, or any artistic organizations. The museum claimed that it made a tactical decision not to publicize the loss for fear of driving the painting underground and decreasing the chances of recovery. The Lubells pur-

166. See DeWeerth, 836 F.2d at 109; Robert A. Barker, Rights Involving Stolen Art, N.Y. L.J., March 25, 1991, at 3.

167. Solomon R. Guggenheim Found. v. Lubell, 569 N.E.2d 426, 429-30 (N.Y. 1991).

168. 569 N.E.2d 426 (N.Y. 1991). 
chased the painting from a gallery in 1967 and exhibited it twice: once in 1967 and again in 1981. A former employee of the Guggenheim who knew the painting was missing recognized a transparency of the painting and alerted the museum, which traced possession to the Lubells. 169

The Lubells defended on the basis of the museum's lack of diligence in searching for the painting. In fact, the museum undertook few, if any, of the efforts the courts demanded of previous plaintiffs; ${ }^{170}$ particularly noteworthy was the museum's failure to contact law enforcement authorities. ${ }^{171}$ The trial court found the museum's behavior unreasonable as a matter of law, but the appellate court found otherwise. It reviewed the decision in DeWeerth and the rules of accrual under New York law, reiterating that the requirement of a demand to an imocent purchaser, "or indeed anyone else whose possession is not tortious," is a substantive element of the cause of action and concluding that "absent a demand there is no cause of action for replevin against a good-faith purchaser, and absent a cause of action the statute cannot begin to run." 172

The DeWeerth court had attempted to mitigate the unreasonable delay doctrine, the appellate court said, by extending it to situations in which knowledge could be imputed to the true owner through a standard of due diligence; in the past, the rule had extended only to situations im which the true owner had actual knowledge of the whereabouts of a piece. The DeWeerth court's rule extended the imquiry past the traditional question of whether the suit was filed im a timely manner after the demand. ${ }^{173}$ The Guggenheim court said that the doctrine developed in DeWeerth was far from what it promised and explicitly rejected the Second Circuit's imposition of a duty of due diligence on owners of stolen

169. Id. at 428.

170. Moreover, the defendant, Mrs. Jules Lubell, suggested that at the least, the museum could have hired private investigators or notified the artist or his cataloguer, both of whom she contacted before purchasing the painting. Barbara Franklin, Suit Reinstated over Chagall Work, N.Y. L.J., Jan. 26, 1990, at 1.

171. This failure is significant since the court reacted so negatively to the plaintiffs similar failure in the DeWeerth case, in which the court found the plaintiff's diligence insufficient to toll the statute. DeWeerth v. Baldinger, 836 F.2d 103, 111-12 (2d. Cir. 1987), cert. denied, 486 U.S. 1056 (1988).

172. Solomon R. Guggenheim Found. v. Lubell, 550 N.Y.S.2d 618, 620 (App. Div. 1990) (emphasis added), affd, 569 N.E.2d 426 (N.Y. 1991).

173. Id. at 620-21. 
art for purposes of accrual. ${ }^{174}$ There is no reason, the court said, to "obscure [the demand rule's] straightforward protection of true owners by creating a duty of reasonable diligence."175 According to the court, imposition of a diligence standard did not eradicate the potential for stale claims; moreover, the DeWeerth court never specified the particular point at which the cause of action actually accrued. ${ }^{176}$ Finally, because New York treats deinand as a substantive element of the cause of action, no proceeding may be imstituted without it. ${ }^{177}$

The Guggenheim court viewed DeWeerth as a decision based on estoppel: "Although the plaimtiff's title to the stolen property might be lawful, she should not be heard to assert it because the delay attributable to her lack of diligence in searching for the property prejudiced the defendant in her defense." 178 The court found that the proper standard in cases of unusual delay is laches, which requires injury to the defendant in addition to delay. ${ }^{179}$ In making laches the applicable defense, the court wisely distributed to the innocent purchaser a portion of the burden of proof that the due diligence requirement had shifted wholly to the true owner. The requirement that mjury be proven mandates that an innocent purchaser present proof that he acted reasonably in purchasing the painting and that he had no notice of the possibility of a claim against the painting when he purchased it. ${ }^{180}$ This requirement also shifts to the subsequent possessor part of the burden of

174. Guggenheim, 569 N.E.2d. at 430.

175. Id.

176. See Guggenheim, 550 N.Y.S.2d at 621. The New York court noted that in DeWeerth, the court stated in a footnote that the limitations period conceptually begins to run when the plaintiff has had the opportunity to use due diligence in both locating the property and making a demand and has failed to do so. $I d$. (citing DeWeerth v. Baldinger, 836 F.2d 103, 107 n.4 (2d Cir. 1987), cert. denied, 486 U.S. 1056 (1988)).

177. This reflects the New York view that until there is a demand and refusal, the subsequent possession is not wrongful. Guggenheim, 569 N.E.2d at 429. In actions in which a demand is a procedural element of the cause of action, New York's three-year statute of limitations runs from the time the right to make deinand is complete, N.Y. CTv. PRAC. L \& R. \& 214(3) (McKinney 1990), typically from the time of the theft. In this case, there can be no cause of action without it; the statute is inapplicable when no demand has been made.

178. Guggenheim, 550 N.Y.S.2d at 621.

179. Id. at 619.

180. The court stated that in this defeuse, the "defendant's vigilance is as anuch in issue as plaintiff's diligence." Id. at 623 . 
investigation. It is an explicit recognition that injury, as well as delay, is required to divest the true owner of title. ${ }^{181}$

Moreover, the lower court questioned whether delay alone could make a replevin action untimely even when the owner had actual knowledge of the whereabouts of the stolen property. ${ }^{182}$ The court declared a policy stance favoring the rightful owner with its pronouncement that "the relative possessory rights of the parties carmot depend upon the mere lapse of time, no matter how long." 183 The Court of Appeals of New York was just as emphatic when it said that "New York case law has long protected the right of the owner whose property has been stolen to recover that property, even if it is in the possession of a good faith purcliaser for value." 184

Finally, the facts of the Guggenheim case suggest the overwhelming difficulty in fashioning a standard of dihgence. Because even members of the art world have not reached a consensus on the best way to approaclı a theft, e.g., whether to publicize the theft or to conduct an internal investigation, the Court of Appeals held that it was "particularly mappropriate" for it to spell out arbitrary rules for dihgent conduct. ${ }^{185}$ In addition, because a number of factors would (properly) influence how a true owner searches for stolen property, the law could not determine how best to proceed. ${ }^{186}$ The demand rule offers a more reliable approach.

181. See also Republic of Turkey v. Metropolitan Museum of Art, 762 F. Supp. 44, 46 (S.D.N.Y. 1990) (requiring proof of injury in order for a subsequent purcliaser to dispute the true owner's title).

182. Guggenheim, 550 N.Y.S.2d at 621 . The court cites some authority to the contrary but continues to refer to lack of diligence as an element of laches. This notion of timeliness is consistent with the New York courts' view that possession is not wrongful until a demand is made. If the innocent purchaser is not in wrongful possession, it is illogical to suppose that a limitations period could be running; no cause of action exists to which the statutory period can apply.

183. Id. at 622. The court expressed the feeling that in some sense, the delay had provided a benefit to the defendant by allowing her many years in possession of the painting during which she could enjoy its exhibition in her home, a benefit she would not ordinarily have experienced. $I d$.

184. Solomon R. Guggenleim Found. v. Lubell, 569 N.E.2d 426, 429 (N.Y. 1991) (citation omitted).

185. Id. at 431.

186. Id. These factors include the value of the property stolen, the manner in which it was stolen, and the type of institution from which it was stolen. The last factor is of particular interest given the tendency of prior court holdings to largely ignore the disparities in resources available to individual and institutional collectors. 
B. Guggenheim as Precedent for Recent Cases

Several courts have followed the Guggenheim court's interpretation of the law in recent decisions. In Republic of Turkey $v$. Metropolitan Museum of $A r t,{ }^{187}$ a federal district court in New York applied the Guggenheim analysis to a motion for summary judgment on Turkey's claims for recovery of cultural artifacts that the museum held. The court determined that the claim of delay made by the party in possession was valid only for purposes of examining the availability of the laches defense. ${ }^{188}$

The defendant, the Metropolitan Museum of Art, attempted to distimguish Guggenheim. It claimed that the Guggenheim court disagreed with DeWeerth only to the extent that DeWeerth extended the unreasonable delay rule to a case in which the true owner had no actual knowledge of the location of the stolen property but in which he could lave had knowledge had he exercised due diligence in investigating the whereabouts of the property. The inuseum attempted to distinguish between the due diligence rule as applied to cases in which the true owner had actual knowledge of all the facts needed to make a demand and as applied to cases in which such knowledge was imputed. The court did not accept this distinction and delried the defendant's motion for summary judgment. ${ }^{189}$

The recent case of Hoelzer v. City of Stamford ${ }^{190}$ also applied the Guggenheim analysis. Although the case did not deal with stolen art, it did address the issues of the rightful possession of art and whether a plaintiff's unreasonable delay in making a demand for property causes the statute of limitations to run. ${ }^{191}$

187. 762 F. Supp. 44 (S.D.N.Y. 1990).

188. Id. at $46-47$.

189. Id. at 47.

190. 933 F.2d 1131 (2d Cir. 1991).

191. The facts of this case are as complex as those of cases involving stolen art. The plaimtiff was an art restorer to whom six murals were delivered in 1971. The murals were a Works Progress Administration project that had hung in a local high school for several years before being removed during reconstruction and madvertently tossed out as trash. Hoelzer supposedly agreed to restore the murals on belialf of the federal government and return them on request. $I d$. at 1133-34.

School district officials did not know the location of the murals until 1980. At that time, a school official visited Hoelzer to inquire about the murals. Although Hoelzer claimed to the contrary, the district court found that he had not asserted ownership at the meeting. In 1986, fifteen years after he originally received the murals, Hoelzer claimed ownership. City and school officials disputed Hoelzer's claim, and in 1989, he 
Although the district court's decision focused largely on the issue of unreasonable delay, the appellate court, referring to Guggenheim, found that unreasonable delay was an inappropriate consideration in the statute of limitations context. ${ }^{192} \mathrm{~A}$ due diligence requirement did not affect the running of the statute because "an owner need not act with due diligence before demanding return of her property." 193 Instead, the statute begins to run when the owner makes a demand for possession and the possessor refuses, "regardless of the apparent imtensity of the owner's search up until that poimt." 194 Moreover, the district court made an interesting observation: when the present possessor was not a goodfaith purchaser (in this case he was entrusted with the murals for restorative services), the possessor would receive a windfall if he were allowed to keep the murals because he neither paid any consideration for them nor had any reasonable expectations in relation to them, save the value of his services performed on them. ${ }^{195}$

\section{Analysis of the Demand Rule}

The demand rule followed by the New York Court of Appeals in Guggenheim is the soundest policy yet apphed in stolen art cases. This doctrine best balances the respective rights of the parties and delegates most equitably the obligations of both innocent purchasers and true owners. This Section examines the aspects of the demand rule that make it preferable to other approaches used by the courts in stolen art cases: its coherence with common law and federal law doctrines; its consistency with the political climate; its potential for clarity and certamty; its inhibitory effect on the burgeoming trade in stolen artwork; and its equitable and effective shifting of the requisite duties of imquiry and investigation to botll parties.

filed suit to quiet title. Id. at 1134-35.

192. Id. at 1136-37.

193. Id. at 1137.

194. Id. at 1138; see also Golden Budha Corp. v. Canadian Land Co. of Am., 931 F.2d 196 (2d Cir. 1991) (reiterating that the three-year statute of linitations does not begin to run until there is a demand for possession and a refusal and that no duty of due diligence is imposed on the owner of stolen property when recovery is sought from an innocent purchaser).

195. Hoelzer v. City of Stamford, 722 F. Supp. 1106, 1113 (S.D.N.Y. 1989), affd, 933 F.2d 1131 (2d Cir. 1991). 
The demand rule is often criticized for reducing "the repose of innocent purchasers to a nullity" by tolling the statute of limitations period until an aggrieved owner has made a demand and allowing aggrieved owners to pursue a cause of action regardless of the passage of time. ${ }^{196}$ However, the Guggenheim court effectively answered this criticism. By emphasizing the availability of the doctrine of laches, the court imposed a burden of investigation on the purchasers of stolen art to determine the authenticity and provenance of the works they contemplate purchasing. If a purchaser meets this burden, he will have genuine repose, unlike the uncertain repose the discovery rule creates by inaking the purchaser's status with regard to title entirely dependent on the actions of the true owner. The additional requirement of injury to the purchaser is not an unreasonable one; if the delay in instituting the action does not injure the purchaser, why should the true owner not be restored to possession? Moreover, the innocent purchaser needs no protection agamst this "harsh" rule through application of a due diligence requirement because other causes of action are available to him, namely breach of implied warranty of title. ${ }^{197}$ The availability of remedies for an innocent purchaser militates against affording him any absolute protection. Instead, the Menzel/Guggenheim rule provides protection for original owners, as well as defenses for innocent purchasers, through the application of laclies and the availability of other causes of action. ${ }^{198}$

One of the demand rule's most promising attributes is its consistency with the common law rule, now codified in the UCC, that even a good-faitl purcliaser camıt obtam valid title from a thief or from one who acquired property from a thief. The coininon law rule was that "le who hath not cannot give."199 Under the UCC, a thief has void title and camiot convey title, good or voidable, even to an innocent purchaser in good faith. A goodfaith purchaser lacks the power to convey vahid title to property to a successor if the property was originally stolen. ${ }^{200}$ The status of

196. Eisen, supra note 22, at 1080 (citing Petrovich, supra note 28, at 1140 ).

197. Drum, supra note 104, at 934-35.

198. Id. at 944 .

199. BLACK'S LAW DICTIONARY, supra note 22 , at 1037.

200. According to the UCC, voidable title can be estabhshed under certain circumstances, but not when the goods have not been exchanged in a voluntary purchase. U.C.C. $\S 2-403(1)(1990)$. Under any definition, a thief cannot be a voluntary purchaser, and under $\S 2-403$, a person receiving stolen goods from a thief, or any person in the 
the innocent purchaser is irrelevant to the validity of the title. ${ }^{201}$ The rule is simple: "A sale by the thief or any other person claiming under the thief does not vest any title in the purchaser as against the owner, though the sale was made in the ordinary course of trade and the purchaser acted in good faith."202

This idea is in direct conflict with the discovery rule, which not only implies that good title passes to the subsequent possessor when the owner fails to pursue a diligent search but also places affirmative obhigations on the true owner. In theory, an original owner should be able to recover his stolen property from any subsequent possessor, even one who pays full price for the piece. The discovery rule, however, mandates that the victim take additional steps to prevent the passing of title to his property, despite the fact that under traditional law, the party in possession has no rightful claim to the property because the thief responsible for its distribution never had title to convey. The demand rule, on the other hand, is consistent with the UCC notion of title, because it confers an automatic right on true owners to demand possession of stolen property.

Furthermore, the Guggenheim decision is in accord with the demonstrated reluctance of politicians to create a statutory due diligence requirement. New York Governor Mario Cuomo, just five years before Guggenheim, vetoed a bill designed to allow museums, and presumably other collectors, to gain valid title to artwork after giving required public notice of acquisition and waiting for a statutorily prescribed period to allow for claims. The bill would have severed the rights of plaintiffs who are not privy to public notices im the United States, especially those that garner little public attention, and who inight not have realized that the artwork had resurfaced. The veto, Governor Cuomo said, was necessary because the period specified in the bill did not provide a "reasonable opportunity" for foreign institutions to receive notice of the acquisition or to take action to recover the property and

line of possession of a thief, receives void title.

201. Inmi-Etti v. Aluisi, 492 A.2d 917, 918 (Md. Ct. Spec. App. 1985) (holding that "a possessor of stolen goods, no matter how innocently acquired, can never convey good title.") (citing Schrier v. Home Indem. Co., 273 A.2d 248 (D.C. 1971)).

202. Suburban Motors v. State Farm Mut. Auto. Ins., 268 Cal. Rptr. 16, 19 (Ct. App. 1990) (quoting 3 RONALD A. ANDERSON, UNIFORM COMMERCIAL CODE 555 (3d ed. 1983)). 
would make New York a "haven for cultural property stolen abroad." ${ }^{203}$

The demand rule is also consistent with the expressed policy of the federal government. Just as the state courts deciding replevin cases have aimed to slow or stop the trade in stolen art, the U.S. Court of Appeals for the Fifth Circuit noted in United States v. $M c$ Clain $^{204}$ that Congress's apparent purpose in enacting stolen property statutes with criminal penalties was to discourage both the theft and the subsequent receipt of stolen goods. ${ }^{205}$ The court further noted that " $[t]$ he ultinate beneficiary of the law . . . is the property owner."206 In McClain, the court dealt with the question of art exported illegally from other countries in contravention of the National Stolen Property Act. ${ }^{207}$ In determining whether the identified property was stolen property belonging to a foreign nation, the court held that "a declaration of national ownership is necessary before illegal exportation of an article can be considered theft, and the exported article considered 'stolen.' "'208 The relevant similarities between a demand requirement to create wrongful possession and a requirement that a country establish a claim of ownership before exportation of artifacts can qualify as theft are clear. In both cases, the deinand is necessary to establish wrongfulness. Thus, the rationale behind New York's common law accrual doctrime accords with federal statutory law on stolen artifacts.

203. Drum, supra note 104, at 936 (quoting Cuomo Vetoes Art Ownership Bill, N.Y. TIMES, July 29, 1986, at C14); see also Irvin Molotsky, 3 U.S. Agencies Urge Veto of ArtClaim Bill, N.Y. TMME, July 23, 1986, at C15 ("We cannot support [the bill] because we feel that it makes recovery of stolen art so difficult that it will encourage theft.") (quoting Dr. Constance Lowenthal, executive director of the International Foundation for Art Research).

The bill was opposed by the U.S. State Department, the U.S. Justice Department, and the U.S. Information Agency because of perceived foreign policy implications. The publication requirements of the bill were minimal, mandating either publication in a collector's own publication, display of the object for twelve months in a 36-month period, or inclusion of the piece in the collector's catalogue for three years. Hence, the bill was viewed as creating an insurmountable burden for small countries or collectors who could not be expected to subscribe to all of the publications and catalogues in which notices might be included. Moreover, a similar measure had previously been withdrawn from the state legislature's consideration because of concerns about the bill's ambiguity in defining which collectors might obtain title under the statute. Id.

204. 545 F.2d 988 (5th Cir. 1977).

205. Id. at 994 .

206. Id.

207. 18 U.S.C. § 2314 (1988).

208. McClain, 545 F.2d at $1000-01$. 
One of the most striking aspects of the Guggenheim decision is that it finally inakes a policy clioice and announces favor for one party. ${ }^{209}$ Witl regard to the statute of limitations, but not the laclies defense, the court clearly took a stand in favor of the true owner. Ideally, in a state sucl as New York, which plays such a vital role in the art industry, the state legislature should announce rules and shape policy clearly determining which parties are to receive legal protection. With this decision, lowever, the court was not making unwarranted intrusions into such pohicymaking prerogatives. The Guggenheim court was not modifying or altering any doctrine; it returned the law to an earlier and more simplified position. The presence of political and historical support for the court's position strengthens the efficacy of its holding. ${ }^{210}$ Indeed, the demand rule is significantly similar to the early doctrine of adverse possession of personal property as it was applied before the importation of the discovery rule. The difficulty of establishing open and notorious possession significant enough to put the true owner on notice of a claim and start the statute of limitations running meant the subsequent possessor of personal property could rarely be expected to win. The deviation from this rule, the discovery rule established in O'Keeffe, expanded the opportunity for parties to defeat the true owner's claims. Hence, a return to the demand rule is not a departure from traditional jurisprudence or an unwarranted judicial excursion into policymaking but a return to the original state of the law.

Another advantage of the demand rule is that of certainty. Balancing equities is a laudable judicial goal, but in these cases, in which innocent purcliasers are threatened with the loss of million dollar investments, certainty seems an equally laudable goal. The discovery rule's inconsistent application hardly comports with the required degree of certainty. With the art theft problem becoining almost epidernic, the Guggenheim court's position, what some

209. Gary Spencer, Claim to Recover Painting Allowed, N.Y. L.J., Feb. 15, 1991, at 1-2 ("For the first time the Court of Appeals has said, as a matter of New York policy, New York is going to favor the true owner of stolen property and is not going to allow the mere lapse of time to cut off ownership.") (quoting Jeffrey Barist, attorney for the Guggenheim Foundation).

210. "New York caselaw has long protected the right of the owner whose property has been stolen to recover that property, even if it is in the possession of a good-faith purchaser for value." Solomon R. Guggenheim Found. v. Lubell, 569 N.E.2d 426, 429 (N.Y. 1991). 
might view as a harsh stance toward innocent purchasers, is entirely appropriate. It is only by forcing both parties to bear a reasonable burden of diligence ${ }^{211}$ that equity and certainty are best served. Without strict guidelines, the discovery rule is destined to be decided again on appeal. ${ }^{212}$

The deinand rule has the added benefit of clarity; it requires no complex or amorphous balancing, nor inust the court determine if an increase in the value of a painting should have an effect on the equities in a replevin suit. By operation of the demand rule, collectors, particularly institutional possessors, can be certain that they will lose possession and receipts from exhibitions if they have been clumsy in checking the cham of title to the works. In this way, the clarity of the demand rule enhances the parties' understanding of their respective rights.

Some observers assert that the deinand rule, like the discovery rule, causes paintings to go further underground because open and notorious use only facilitates the true owner's ability to locate the painting and demand possession. However, the effect of the demand rule in this regard may be less noticeable than that of the discovery rule for at least two reasons. First, the requirement of diligence under the discovery rule inandates that the true owner inake a public and thorough search for the lost item, increasing the likelihood that the subsequent possessor will become aware of the true owner's efforts and that he will hide the piece if he senses he might lose possession of so valuable an imvestment. The operation of the demand rule does not require so public a search. Second, under the demand rule, the law does not treat the subsequent possession as wrongful until a deinand for possession is made. The possessor has no reason to hide the painting. By contrast, under the discovery rule, the subsequent possession remams wrongful throughout the statutory period and for the duration of the true owner's diligent efforts. The subsequent possessor in that case has every reason to keep the piece underground. To the

211. The court did not abolish the true owner's duty of diligence in not causing an unreasonable delay in the making of a demand once the subsequent possessor has been found. What the Guggenheim decision eradicated was the imposition of a due diligence standard in searching for the location of stolen property so that a denand could be inade. Id. at 427,430 .

212. See, e.g., DeWeerth v. Baldinger, 658 F. Supp. 688 (S.D.N.Y.), rev'd, 836 F.2d 103 (2d Cir. 1987), cert. denied, 486 U.S. 1056 (1988); O’Keeffe v. Snyder, 405 A.2d 840 (N.J. Super. Ct. App. Div. 1979), rev'd, 416 A.2d 862 (N.J. 1980). 
extent that either doctrine produces this sequestration effect, the demand rule seems to resolve the situation more equitably by protecting the owner with valid title im his efforts to locate the stolen property, rather than imposing a burden on him that almost certainly makes recovery of the stolen property impossible. Under the discovery rule, subsequent possessors must be aware that at some point the true owner will face the decision of whether to abandon the effort and intensity of a diligent search and thereby lose title to the property. The subsequent possessor gains an advantage, therefore, by hiding the painting until that point.

The demand rule as it applies in New York shifts the primary burden of investigation to the purchaser. The true owner is not without some obligation because, as the courts have noted, the true owner must not unreasonably delay in making a demand on the party in possession once he learns the whereabouts of the stolen piece. ${ }^{213}$ The remaining obligation, however, falls on the purchaser. Of course, the rule imposes some degree of obligation on purchasers imitially in order to qualify as innocent, good-faith purchasers. ${ }^{214}$ Yet, if prospective purchasers seek repose, the Guggenheim decision thrusts upon them a higher duty of inquiry. This result is logical because purchasers of paintings have better opportunities to verify the provenance of works of art than owners have in trying to locate or uncover stolen pieces. In considering a purchase, many persons seek the aid of an art dealer who has both the resources and the ability to investigate the validity of the object's title and who can reasonably be expected to undertake such an investigation. Moreover, a purchaser has the opportunity to question the seller as to the circumstances of his acquisition of the piece and to inquire with art registries and law enforcement agencies as to the status of the piece. As the Goldberg court noted, purchasers can examine the circumstances of the proposed purchase and at least be put on notice that the property may be stolen. ${ }^{215}$ Even if a purchaser is not technically put on notice, it

213. See DeWeerth, 836 F.2d at 107.

214. U.C.C. § 1-201(9) (1990); id. § 2-403(2).

215. Autocephalous Greek-Orthodox Church of Cyprus v. Goldberg \& Feldman Fine Arts, Inc., 717 F. Supp. 1374, 1381 (S.D. Ind. 1989), affd, 917 F.2d 278 (7th Cir. 1990), cert. denied, 112 S. Ct. 377 (1992). In Goldberg, the purchaser knew that the art dealer with whom she was working had previously been convicted of forging an artist's signature and had been sued for failing to pay an art gallery. Instead of inquiring further into his credibility, the purchaser dealt with him anyway. Moreover, she trusted his attoruey. Id. 
may not be unreasonable to expect that he be on notice that further verification is required. Some commentators have suggested that authorities in the art world would prefer that "as between an innocent owner and innocent purchaser, it is the latter who should bear the loss ... [ [for several reasons, including] his voluntary entry "imto a transaction to acquire material of a type known to be problematic." "216

The burden on the purchaser seems even more defensible in light of several other factors. The rule imposes a duty on the purchaser ouly to the extent lie desires to avoid eventual liability. Furthermore, there is no objective level of "diligent" activity in which the purchaser must engage before a court will recognize his activities as sufficient to invoke a legal right. The efforts undertaken are for the purchaser's own protection. Under the discovery rule, however, the requirement of due diligence is a judicially created, objective standard that stands between the true owner of stolen property and his exercise of the right to recover that property. A solid and well-defined notion of a diligent search is necessary, but the experience of the courts has slown that this is nearly impossible to codify. ${ }^{217}$

To the extent that the demand rule places liability on those who purchase stolen paintings, it takes a giant step toward slowing the art theft trade. Deterrence no doubt stems from the fact that the purcliaser stands to lose an important investment if he must return to the true owner a stolen painting purchased for a substantial sum of money: "It means that people will be less likely to buy stolen art ... and more likely to ask questions."218 Yet this is not the only deterrent underlying the demand rule. If purcliasers are unwilling to purchase stolen items, thieves may be deterred from frequent leists. Furthermore, the imposition of the burden on the purchaser affects the integrity of the art market as a whole.

216. Solomon R. Guggenheim Found. v. Lubell, 550 N.Y.S.2d 618, 622 (App. Div. 1990) (quoting Stephen E. Weil, Repose, 8 IFAR REPORTS, Aug.-Sept. 1987, at 6), affd, 569 N.E.2d 426 (N.Y. 1991).

217. Guggenheim, 569 N.E.2d at 431 ("[I]t would be difficult, if not impossible, to craft a reasonable diligence requirement that could take into account all of these variables[, such as the value of the stolen property, the manner of theft, and the type of institution from which the property was stolen] .....").

218. Sam H. Verhovek, Guggenheim May Sue for Chagall, N.Y. TiMES, Feb. 14, 1991, at $C 7$ (quoting Dr. Constance Lowenthal, executive director of the International Foundation for Art Research). 
In Porter $v$. Wertz, ${ }^{219}$ in the context of art merchant transactions and sales, the court noted that "commercial indifference to ownership or the right to sell facilitates traffic in stolen works of art" and that "[c]ommercial indifference diminishes the integrity and $\mathrm{m}$ creases the culpability of the apathetic merchant."220 As the court in Goldberg noted, "Lest this result seem too harsh, we should note that those who wish to purchase artwork on the international market, undoubtedly a ticklish business, are not without means by which to protect themselves .... [P]rospective purchasers would do best to do more than make a few last-minute phone calls."221

Finally, the demand rule's anomalous favoring of the thief over the innocent purchaser is illusory. Although the Guggenheim court failed to explain New York's separate statutory treatment of innocent purchasers and thieves, the effect may be a nullity. As noted earher, the statute does not begin to run against a thief who has fraudulently concealed the property. ${ }^{222}$ The statute is tolled until the owner either knows the location of the stolen property or could have known with the exercise of effort. The thief who has sold a stolen painting, merely by virtue of a sale unbeknownst to the true owner, may have fraudulently concealed the whereabouts of the painting, tolling the statute against the thief as well as the innocent purchaser. Moreover, if, as the Oklahoina Supreme Court suggested in Weaver $v$. Casey, ${ }^{223}$ identity of the defendant is an essential element of the cause of action, the demand rule in no way favors the thief because the statute will be tolled until the time demand can be made. ${ }^{224}$ At any rate, the ordinary art thief does not intend to retain the stolen property long enough to imvoke the statute of limitations. More often, the property will have been sold to an innocent purchaser, against whoin the state's lenient demand rule protects the true owner.

219. 416 N.Y.S.2d 254 (App. Div. 1979), affd, 439 N.Y.S.2d 105 (1981).

220. Id. at 259.

221. Autocephalous Greek-Orthodox Church of Cyprus v. Goldberg \& Feldman Fine Arts, Inc., 917 F.2d 278, 294 (7th Cir. 1990), cert. denied, 112 S. Ct. 377 (1992).

222. 'See supra Section I(B).

223. 816 P.2d 1126 (Okla. 1991).

224. Id. at 1130. The Guggenheim court noted that New York law provides that the cause of action accrues at the time of the theft, regardless of whether the owner is aware of the theft. However, it does not rule out the possibility that the statute might be tolled if the owner does not know the identity of the thief. Solomon R. Guggenheim Found. v. Lubell, 569 N.E.2d 426, 429 (N.Y. 1991). 
Since few courts recognize the statute of limitations in replevin actions as a statute of repose in itself, but more often as an obstacle to the true owner's suit, there is internal consistency to the New York rule. In actions against the thief, the statute of limitations operates to bar the true owner's remedy, but the right to possession remains vested in the owner. ${ }^{225}$ In the case of innocent purchasers, the statute assumes that the possession is not wrongful and that the innocent purchaser consequently has the right to possession. Once the possession becomes wrongful-that is, after a demand is made-the statute of limitations becomes applicable as a bar to the owner's remedy, just as it applies agamst the thief. Because an innocent purchaser suffers no legal exposure until he has been made aware of a pending claim, the statutory period to which he is subject is no longer than that applicable to the thief.

\section{CONCLUSION}

The courts have long had difficulty determining tlie best inethod of ruling on the accrual of the statute of limitations in replevin actions to recover stolen art. Althougli several approaches have been taken, the best is the demand rule affirmed by the New York Court of Appeals in Guggenheim. The discovery rule, which shifts tlie burden of locating stolen artwork to the true owner and forecloses the rights of the owner in the event his burden is not inet, encourages trafficking in art theft because a purcliaser, regardless of his good faith, can retain possession of a stolen piece unless the true owner maintains a vaguely defined diligent search for the piece. The Guggenheim court's opimion that the better policy is protection of the true owner by placement of a heavier burden of investigation on the purchaser is a nore equitable choice. The purchaser is not left without a defense; lie may assert laches. Moreover, although the law appears facially imconsistent im its treatment of thieves and innocent purchasers, it is in fact not partial to the thief. In any case, in New York at least, art collectors are well-advised to "buy the piece, never the story."226

225. No action may be pursued against the thief, but the true owner retains the right to initiate an action against the current possessor to whom the thief sold the piece.

226. Karl E. Meyer, "Buy the Piece, Never the Story," N.Y. TMES, Aug. 20, 1989, \& 4, at 22 (quoting eminent American collector Norbert Schimmel). 